\title{
Taxonomic revision of the Lycocerus hanatanii species group (Coleoptera, Cantharidae), with the description of new species from Taiwan
}

\author{
Yun HSIAO ${ }^{1}$, Yûichi OKUSHIMA ${ }^{2}$, Ping-Shih YANG ${ }^{3} \&$ Chiun-Cheng KO ${ }^{4, *}$ \\ ${ }^{1,3,4}$ Department of Entomology, National Taiwan University, No. 27, Lane 113, Sec. 4, \\ Roosevelt Rd., Taipei 10617, Taiwan. \\ ${ }^{2}$ Kurashiki Museum of Natural History, Chûô 2-6-1, Kurashiki-shi, \\ Okayama Pref., 710-0046 Japan. \\ *Corresponding author: kocc2501@,ntu.edu.tw \\ ${ }^{1}$ Email: yunhsiao@outlook.com \\ ${ }^{2}$ Email: musoku@city.kurashiki.okayama.jp \\ ${ }^{3}$ Email: psyang@ntu.edu.tw \\ ${ }^{1}$ urn:1sid:zoobank.org:author:6E5C734A-1809-46A1-A595-5A0CB7B39BA0 \\ ${ }^{2}$ urn:1sid:zoobank.org:author:BB590861-E5AE-438B-AC0E-A8724F8FAAB5 \\ ${ }^{3}$ urn:Isid:zoobank.org:author:0CD84731-DCC1-4A68-BE78-E543D35FA5A2 \\ ${ }^{4}$ urn:1sid:zoobank.org:author:290CF231-2518-4C91-A2EA-C184C9728C7F
}

\begin{abstract}
The Lycocerus hanatanii species group is revised, with the addition of seven taxa: L. araticollis (Fairmaire, 1897), L. nigripennis (Pic, 1938), L. griseopubens (Pic, 1928), L. yitingi Hsiao \& Okushima sp. nov., L. aurantiacus Hsiao \& Okushima sp. nov., L. evangelium Hsiao \& Okushima sp. nov. and L. kintaroi Hsiao \& Okushima sp. nov. Supplementary descriptions of the males of L. araticollis and L. griseopubens are provided. Lycocerus nigripennis (Pic, 1938) and L. pictus (Wittmer, 1983) are redescribed in detail. Each species is provided with photos or illustrations of genitalia of both sexes and abdominal ventrite VII of the female if available. Distribution maps and a key to the species of the $L$. hanatanii species group are presented. In addition, the monophyly of the L. hanatanii species group is supported based on a morphological phylogenetic analysis.
\end{abstract}

Keywords. Soldier beetles, taxonomy, new taxa, classification, Asia.

Hsiao Y., Okushima Y., Yang P.-S. \& Ko C.-C. 2016. Taxonomic revision of the Lycocerus hanatanii species group (Coleoptera, Cantharidae), with the description of new species from Taiwan. European Journal of Taxonomy 170: 1-33. http://dx.doi.org/10.5852/ejt.2016.170

\section{Introduction}

The genus Lycocerus Gorham, 1889 is a highly species-rich taxon in Asia, with more than 300 species and distributed in the Oriental and eastern Palaearctic regions (Kazantsev \& Brancucci 2007). Okushima (2005) revised the Japanese fauna of Lycocerus and proposed 9 species groups with 23 subgroups based 
on morphological characters, including external morphology and the genital organs of both sexes. Okushima \& Brancucci (2008) and Yang et al. (2014) proposed two more species groups based on species from Laos, Vietnam and China. All of the Japanese species and several species from China, Taiwan, India and the Indo-China Peninsula were included in these defined species groups (Okushima 2005, 2007a, 2007b; Okushima \& Brancucci 2008; Yang \& Yang 2011; Okushima \& Yang 2013; Yang et al. 2014; Hsiao \& Okushima 2015). However, there has been no systematic study to examine the monophyly of each species group or to clarify their relationship using a phylogenetic analysis.

The Lycocerus hanatanii species group is characterized by the following combination of characters: small-sized body; small and not very prominent eyes; knife-shaped and slender apical maxillary palpomere; filiform antennae, not exceeding half of elytral length, without groove; subquadrate pronotum; both sexes with simple tarsal claws; laterophyses of aedeagus very short, barely visible or invisible in lateral view; long spermathecal duct; spermatheca provided with a spiral tube. So far only three species, L. hanatanii (Okushima, 1996), L. ueharaensis (Okushima, 1996) and L. pictus (Wittmer, 1983), have been included (Okushima 2005).

In this study, we aim to revise the fauna of this species group, with the addition of three new members, L. araticollis (Fairmaire, 1897), L. nigripennis (Pic, 1938) and L. griseopubens (Pic, 1928), and the description of four new taxa, L. yitingi Hsiao \& Okushima sp. nov., L. aurantiacus Hsiao \& Okushima sp. nov., L. evangelium Hsiao \& Okushima sp. nov., and L. kintaroi Hsiao \& Okushima sp. nov. We also use a morphology-based phylogenetic approach to support our classification and confirm the monophyly of the L. hanatanii species group.

\section{Materials and methods}

The materials examined in this paper are deposited in the following institutions and personal collection:

BMNH $=$ Natural History Museum, London, UK
CAS $=$ California Academy of Sciences, San Francisco, USA
CBM $=$ Natural History Museum and Institute, Chiba, Japan
EUMJ $=$ Ehime University Museum, Matsuyama, Japan
KURA $=$ Kurashiki Museum of Natural History, Kurashiki, Japan
MNHN $=$ Muséum national d'Histoire naturelle, Paris, France
NHMB $=$ Naturhistorisches Museum Basel, Switzerland
NMNS $=$ National Museum of Natural Science, Taichung, Taiwan
SDEI $=$ Senckenberg, Deutsches Entomologisches Institut, Müncheberg, Germany
TARI $=$ Taiwan Agricultural Research Institute, Wufeng, Taichung, Taiwan
YHC $=$ Y. Hsiao's private collection

The terminology used in the descriptions and the methods employed follow those of Okushima (2005) and Hsiao (2015), but Double Stain (BioQuip, USA) was used for the staining of female genitalia. The distribution map was prepared using the SimpleMappr program (Shorthouse 2010), based on the label data of examined material in this study. Some old names or supplementary information on localities are updated in square brackets [ ] if necessary. The type specimen data are quoted verbatim: [p] indicates that the following data are printed and [h] that they are handwritten. A double backslash (//) is used to separate data from different labels and a single one (/) to separate data from different lines on the same label. Abbreviations:
ex $=$ specimen $/ \mathrm{s}$
$\mathrm{ag}=$ accessory gland
$\mathrm{di}=$ diverticulum 


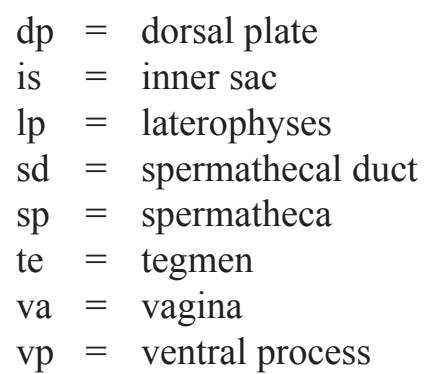

Following Okushima (2005), Kasantsev (1999) and our observations, 29 adult morphological characters and 1 geographical character were used for the phylogenetic analysis as follows:

01 Body size: (0) small (5-7mm); (1) medium (8-10mm); (2) large (>10mm).

02 Body form judged on the ratio of the length to the width at the widest part of the conjoint elytra: (0) stout (about 2.2); (1) middle (about 2.5-3.0); slender (mainly greater than 3.0).

03 Antennal length in males: (0) exceeding $1 / 2$ elytral length; (1) extending to $1 / 2$ elytral length.

04 Antennal length in females: (0) extending to $1 / 2$ of elytral length; (1) barely exceeding the humeri, but not extending to $1 / 2$ of elytral length.

05 Form of antennae: (0) filiform; (1) serrate.

06 Grooves on male antennal segments: (0) absent; (1) present.

07 Shape of terminal maxillary palpomere: (0) stout (Fig. 1A); (1) subtriangular (Fig. 1B); (2) slender (Fig. 1C).

08 Size of eyes: (0) large and prominent (Fig. 1D); (1) small and not very prominent (Fig. 1E).

09 Vertex: (0) flat and glabrous; (1) faintly hollowed and distinctly punctate.

10 Form of pronotum: (0) trapezoid (Fig. 1F); (1) subquadrate (Fig. 1G); (2) flattened and rectangular (Fig. 1H).

11 Greatest width of pronotum in male: (0) wider than head; (1) nearly as wide as head; (2) narrower than head.

12 Angular convexity on pronotum: (0) distinct (Fig. 1G); (1) indistinct.

13 Form of elytra: (0) subparallel at the sides; (1) apically expanded; (2) moderately narrowed apically; (3) strongly narrowed apically.

14 Costae on elytra: (0) distinct; (1) hardly recognizable.

15 Size of legs: (0) stout (Fig. 1I); (1) slender (Fig. 1J).

16 Form of male claws: (0) all claws simple; (1) each outer claw of fore and middle legs with tooth.

17 Form of female claws: (0) all claws simple; (1) each outer claw of fore and middle legs with tooth.

18 Dorsal plate of each paramere of aedeagus: (0) fused or nearly fused; (1) separated.

19 Inner surface of dorsal plate of aedeagus: (0) modified, with processes; (1) simple.

20 Laterophyses of aedeagus: (0) nearly fused; (1) widely separated on both sides of median lobe.

21 Laterophyses of aedeagus: (0) long, distinctly visible in lateral view; (1) short, barely visible or invisible in lateral view.

22 Apical part of median lobe of aedeagus: (0) widened apically; (1) strongly narrowed apically; (2) moderately narrowed apically.

23 Apical part of vagina: (0) broad; (1) extended apically as a thick duct.

24 Shape of diverticulum: (0) short, thick and rod-shaped; (1) long and thin; (2) short and thin.

25 Spermathecal duct: (0) absent; (1) present.

26 If spermathecal duct present, length of spermathecal duct: (0) short; (1) long.

27 Shape of spermatheca: (0) short, sac-shaped; (1) long and thin, provided with spiral tube(s).

28 If spermatheca long and thin: (0) provided with a spiral tube; (1) provided with two spiral tubes.

29 Shape of accessory gland: (0) simple (thin, filiform); (1) modified (abruptly expanded).

30 Distribution: (0) continental; (1) insular. 
Table 1. Data matrix.

\begin{tabular}{|c|c|c|c|c|c|c|c|c|c|c|c|c|c|c|c|c|c|c|c|c|c|c|}
\hline$\underset{\tilde{z}}{\tilde{*}}$ & 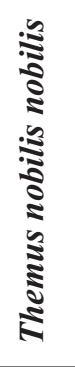 & 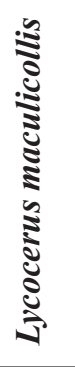 & 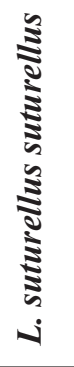 & 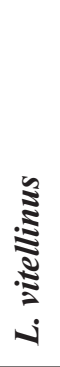 & 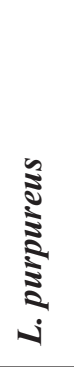 & 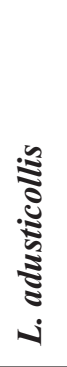 & 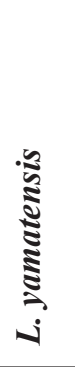 & 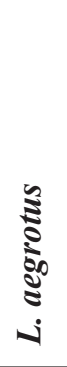 & 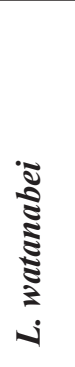 & 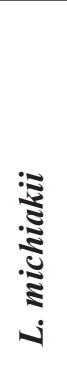 & 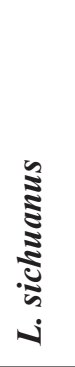 & 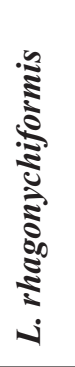 & 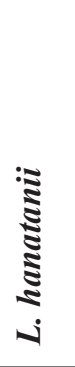 & 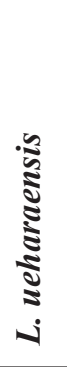 & 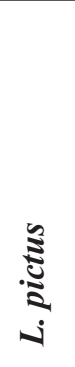 & 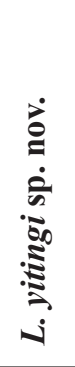 & 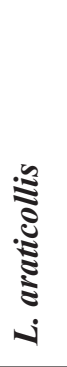 & 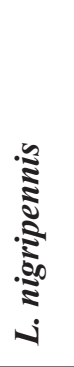 & 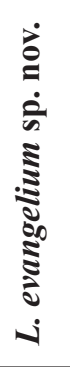 & 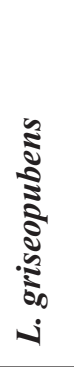 & 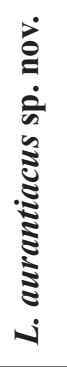 & 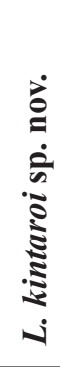 \\
\hline 01 & 2 & 2 & 2 & 1 & 0 & 1 & 1 & 1 & 2 & 1 & 1 & 0 & 0 & 0 & 0 & 0 & 0 & 0 & 0 & 0 & 0 & 0 \\
\hline 02 & 0 & 0 & 1 & 1 & 0 & 1 & 1 & 1 & 2 & 2 & 2 & 1 & 1 & 1 & 1 & 1 & 1 & 1 & 1 & 1 & 1 & 1 \\
\hline 03 & 1 & 0 & 0 & 0 & 1 & 0 & 0 & 0 & 0 & 0 & 0 & 0 & 1 & 1 & 1 & 1 & 1 & 0 & 1 & $?$ & 0 & 1 \\
\hline 04 & 1 & 1 & 0 & 0 & 1 & 0 & 0 & 0 & 0 & 0 & 0 & 0 & 1 & 1 & 1 & 1 & $?$ & 1 & 1 & 1 & 1 & $?$ \\
\hline 05 & 0 & 1 & 0 & 0 & 0 & 0 & 0 & 0 & 0 & 0 & 0 & 0 & 0 & 0 & 0 & 0 & 0 & 0 & 0 & 0 & 0 & 0 \\
\hline 06 & 1 & 0 & 1 & 1 & 0 & 1 & 1 & 1 & 0 & 1 & 1 & 0 & 0 & 0 & 0 & 0 & 0 & 0 & 0 & $?$ & 0 & 0 \\
\hline 07 & 0 & 1 & 1 & 2 & 0 & 1 & 2 & 1 & 1 & 1 & 1 & 1 & 2 & 2 & 2 & 2 & 2 & 2 & 2 & 2 & 2 & 2 \\
\hline 08 & 0 & 0 & 0 & 0 & 0 & 0 & 0 & 0 & 0 & 0 & 0 & 1 & 1 & 1 & 1 & 1 & 1 & 1 & 1 & 1 & 1 & 1 \\
\hline 09 & 0 & 0 & 1 & 1 & 1 & 1 & 1 & 1 & 1 & 1 & 1 & 1 & 1 & 1 & 1 & 1 & 1 & 1 & 1 & 1 & 1 & 1 \\
\hline 10 & 2 & 0 & 1 & 1 & 0 & 1 & 1 & 1 & 1 & 1 & 0 & 1 & 1 & 1 & 1 & 1 & 1 & 1 & 1 & 1 & 1 & 1 \\
\hline 11 & 0 & 0 & 1 & 1 & 1 & 2 & 2 & 1 & 1 & 1 & 2 & 2 & 1 & 1 & 1 & 1 & 1 & 1 & 1 & 1 & 1 & 1 \\
\hline 12 & 1 & 1 & 1 & 1 & 1 & 1 & 1 & 0 & 1 & 1 & 1 & 0 & 0 & 0 & 0 & 0 & 0 & 0 & 0 & 0 & 0 & 0 \\
\hline 13 & 2 & 1 & 0 & 0 & 0 & 0 & 0 & 0 & 0 & 3 & 0 & 0 & 0 & 0 & 0 & 0 & 0 & 0 & 0 & 0 & 0 & 0 \\
\hline 14 & 1 & 0 & 1 & 1 & 1 & 1 & 1 & 1 & 1 & 1 & 1 & 1 & 1 & 1 & 1 & 1 & 1 & 1 & 1 & 1 & 1 & 1 \\
\hline 15 & 1 & 0 & 1 & 1 & 1 & 1 & 1 & 1 & 1 & 1 & 1 & 1 & 1 & 1 & 1 & 1 & 1 & 1 & 1 & 1 & 1 & 1 \\
\hline 16 & 0 & 0 & 0 & 1 & 1 & 0 & 1 & 0 & 0 & 0 & 1 & 0 & 0 & 0 & 0 & 0 & 0 & 0 & 0 & 0 & 0 & 0 \\
\hline 17 & 0 & 1 & 1 & 1 & 1 & 0 & 1 & 1 & 0 & 1 & 1 & 0 & 0 & 0 & 0 & 0 & $?$ & 0 & 0 & 0 & 0 & $?$ \\
\hline 18 & 0 & 1 & 1 & 1 & 1 & 1 & 1 & 1 & 1 & 1 & 1 & 1 & 1 & 1 & 1 & 1 & 1 & 1 & 1 & 1 & 1 & 1 \\
\hline 19 & 0 & 0 & 1 & 1 & 1 & 1 & 1 & 1 & 1 & 0 & 1 & 1 & 1 & 1 & 1 & 1 & 1 & 1 & 1 & 1 & 1 & 1 \\
\hline 20 & 0 & 1 & 1 & 1 & 1 & 1 & 1 & 1 & 1 & 1 & 1 & 1 & 1 & 1 & 1 & 1 & 1 & 1 & 1 & 1 & 1 & 1 \\
\hline 21 & 0 & 0 & 0 & 0 & 0 & 0 & 0 & 0 & 0 & 0 & 0 & 0 & 1 & 1 & 1 & 1 & 1 & 1 & 1 & 1 & 1 & 1 \\
\hline 22 & 0 & 2 & 2 & 2 & 2 & 2 & 2 & 2 & 2 & 2 & 2 & 1 & 1 & 1 & 1 & 1 & $?$ & 1 & 1 & 1 & 1 & 1 \\
\hline 23 & 0 & 0 & 1 & 0 & 0 & 0 & 0 & 1 & 0 & 0 & 0 & 1 & 1 & 1 & 1 & 1 & $?$ & 1 & 1 & $?$ & 1 & ? \\
\hline 24 & 0 & 1 & 1 & 1 & 1 & 2 & 1 & 1 & 1 & 2 & 1 & 1 & 1 & 1 & 1 & 1 & $?$ & 1 & 1 & $?$ & 1 & $?$ \\
\hline 25 & 0 & 1 & 1 & 1 & 1 & 1 & 1 & 1 & 1 & 1 & 1 & 1 & 1 & 1 & 1 & 1 & $?$ & 1 & 1 & $?$ & 1 & $?$ \\
\hline 26 & - & 0 & 0 & 0 & 0 & 0 & 0 & 1 & 1 & 0 & 0 & 1 & 1 & 1 & 1 & 1 & $?$ & 1 & 1 & $?$ & 1 & ? \\
\hline 27 & 0 & 1 & 1 & 1 & 1 & 1 & 1 & 1 & 1 & 1 & 1 & 1 & 1 & 1 & 1 & 1 & $?$ & 1 & 1 & $?$ & 1 & ? \\
\hline 28 & - & 0 & 0 & 0 & 1 & 0 & 0 & 0 & 1 & 0 & 0 & 0 & 0 & 0 & 0 & 0 & $?$ & 0 & 0 & $?$ & 0 & $?$ \\
\hline 29 & 0 & 0 & 0 & 0 & 1 & 0 & 0 & 0 & 0 & 0 & 0 & 0 & 0 & 0 & 0 & 0 & $?$ & 0 & 0 & $?$ & 0 & $?$ \\
\hline 30 & 0 & 0 & 1 & 1 & 0 & 1 & 1 & 1 & 1 & 0 & 0 & 1 & 1 & 1 & 1 & 1 & 0 & 1 & 1 & 0 & 1 & 1 \\
\hline
\end{tabular}

The ingroup taxa include 3 Lycocerus species previously attributed to the L. hanatanii Group in Okushima (2005) and 6 species we herein attribute to this species group, L. rhagonychiformis (Wittmer, 1983) and one representative species of each defined species group, including L. maculicollis (Hope, 1831), L. suturellus suturellus (Motschulsky, 1860), L. vitellinus (Kiesenwetter, 1874), L. purpureus Kazantsev, 2007, L. adusticollis (Kiesenwetter, 1874), L. yamatensis Okushima, 2005, L. watanabei 
(Ishida \& M. Satô, 1993), L. aegrotus (Kiesenwetter, 1874), L. michiakii Okushima \& Brancucci, 2008 and L. sichuanus Y. Yang \& X. Yang, 2014. The outgroup taxon is Themus (Themus) nobilis nobilis (Gorham, 1889). The data matrix (Table 1) was coded and edited with WinClada ver. 10.00.08 (Nixon 2002). Inapplicable data were coded as "-" and missing data were coded with "?". Most characters were based on our own observations. The data matrix was analyzed using NONA ver. 2.0 (Goloboff 1999) from WinClada. All characters were run equally weighted and not additive. The commands of heuristic analysis, 'hold 10000', 'hold/20', 'mult*50' and 'mult*max*' were used to search for the most parsimonious tree(s). In the resultant trees, the unsupported nodes were hard collapsed and only the best trees were kept in WinClada. The characters and character states on the tree were optimized using unambiguous character changes in WinClada.

\section{Results}

\section{Phylogenetic analysis of the $\mathbf{L}$. hanatanii species group}

The heuristic analysis resulted in 10 most parsimonious trees (L 63; CI 61; RI 80) and their strict consensus tree (L 72; CI 54; RI 72) is used in the discussion (Fig. 9). The monophyly of the L. hanatanii species group is supported by several synapomorphies: relatively short antennae, slender apical maxillary palpomere and very short laterophyses of the aedeagus. Lycocerus rhagonychiformis (Wittmer, 1983) is presented as the sister group of the L. hanatanii species group, which shows high morphological similarity to it. However, the relationships between the clade L. hanatanii Group + L. rhagonychiformis and the other species groups are presented as an unresolved bush. Hence, the phylogenetic position of this clade remains unknown.

\section{Taxonomy}

\section{Key to the species of the $L$. hanatanii species group}

1. Coloration: mostly yellowish or blackish, with wide yellowish stripe on head, pronotum and elytra, respectively

- Coloration: mostly blackish; pronotum completely black or fringed with yellowish margins or orange to yellowish brown, with black marking in middle; elytra completely black, or with small and slender yellowish brown stripes on humeri

2. Head black, with frons yellowish; pronotum yellowish brown, with a large black marking in middle; aedeagus: dorsal plate of each paramere nearly touching on inner margin (Fig. $1 \mathrm{~K}$ ) ...................... 3

- Head dark yellow, with a black marking on the vertex; pronotum dark yellow, with a longitudinal black marking in middle, elytra completely pale yellow or fuscous, with pale yellow longitudinal stripe on each elytron; aedeagus: dorsal plate of each paramere concave on inner margin (Fig. 1L)

3. Aedeagus: ventral process expanded apically, curved inwards; dorsal plate with a rounded apex; laterophyse acute and barely visible in lateral view

L. hanatanii (Okushima, 1996)

- Aedeagus: ventral process almost straight and slightly curved inwards; dorsal plate with a pointed apex; laterophyse stout and invisible in lateral view

L. ueharaensis (Okushima, 1996)

4. Elytra completely pale yellow; aedeagus: laterophyse with pointed apex (Fig. 3B)

L. pictus (Wittmer, 1983)

- Elytra fuscous, with wide pale yellow longitudinal stripe on each elytron; aedeagus: laterophyse with truncated apex (Fig. 3E) L. yitingi Hsiao \& Okushima sp. nov.

5. Aedeagus: dorsal plate of each paramere nearly touching on inner margin (Fig. 1K)

- Aedeagus: dorsal plate of each paramere concave on inner margin (Fig. 1L) . .6 9 
6. Pronotum completely black; aedeagus: apical margin of dorsal plate truncated (Fig. 4B) L. araticollis (Fairmaire, 1897)

- Pronotum completely black or orange, with a black marking in middle; aedeagus: apical margin of dorsal plate rounded (Fig. 4C, G, J)

7. Coloration of pronotum varying from completely black or orange, with a black marking in middle; aedeagus: dorsal plate longer than ventral process

L. nigripennis (Pic, 1938)

- Coloration of pronotum uniform, orange, with a black marking in middle; aedeagus: dorsal plate nearly as long as ventral process

8. Surface of body lusterless; aedeagus: ventral process moderately expanded apically, curved inwards

L. griseopubens (Pic, 1928)

- Surface of body semilustrous; aedeagus: ventral process strongly expanded apically, slightly curved inwards

L. aurantiacus Hsiao \& Okushima sp. nov.

9. Body and legs nearly black; aedeagus: apex of laterophyse more slender and acute (Fig. 5B) L. evangelium Hsiao \& Okushima sp. nov.

- Pronotum black, fringed with yellowish margins; aedeagus: apex of laterophyse far from apical margin of dorsal plate in lateral view (Fig. 5E)

L. kintaroi Hsiao \& Okushima sp. nov.
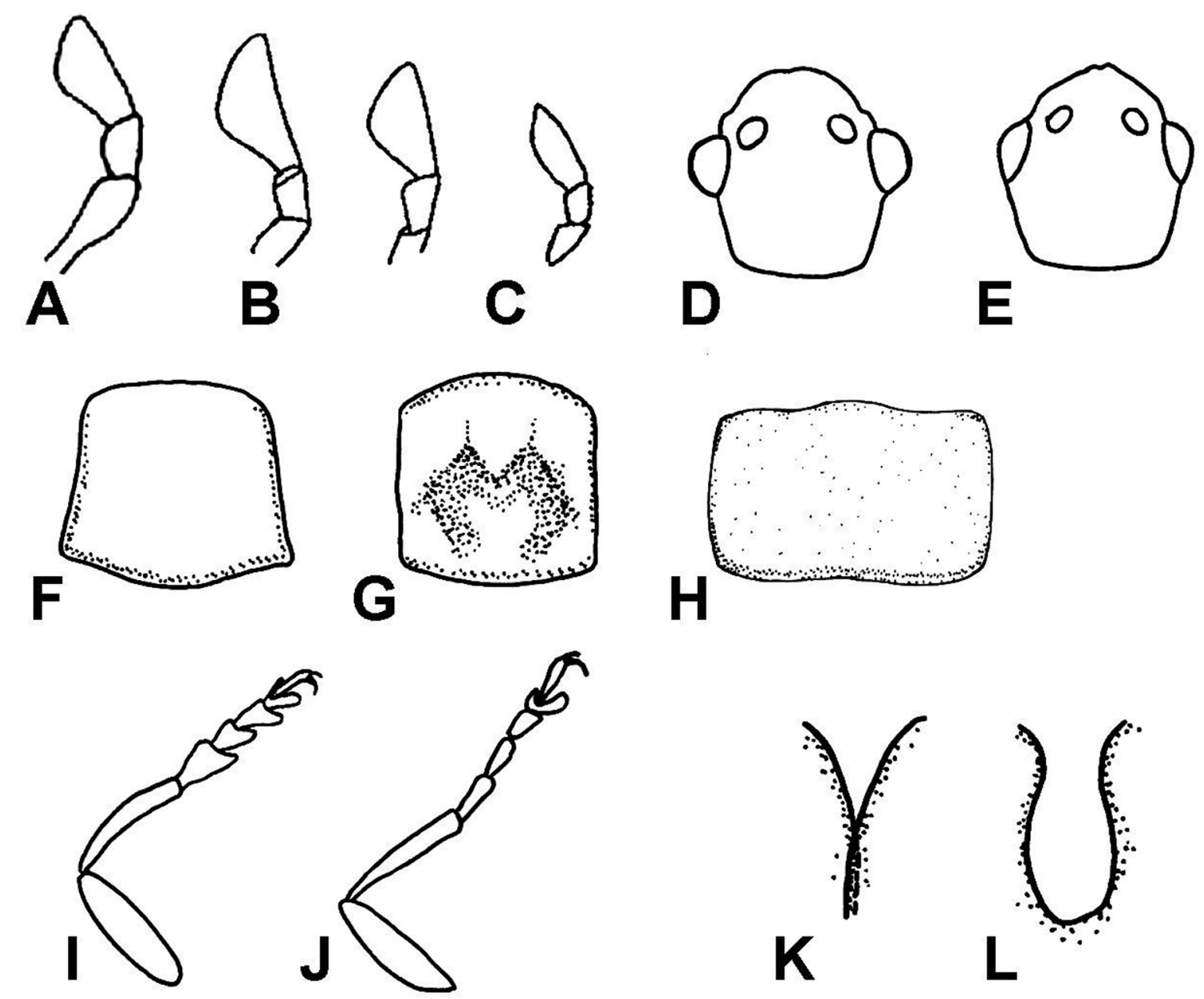

Fig. 1. Morphological characters used for the phylogenetic analysis and key. A-C. Terminal maxillary palpomere. D-E. Eyes. F-H. Pronotum. I-J. Leg. K-L. Inner margin of dorsal plate of aedeagus. 
Class Hexapoda Blainville, 1816

Order Coleoptera Linnaeus, 1758

Superfamily Elateroidea Leach, 1815

Family Cantharidae Imhoff, 1856

Genus Lycocerus Gorham, 1889

\section{Lycocerus hanatanii Group}

Lycocerus hanatanii (Okushima, 1996)

Athemellus hanatanii Okushima, 1996: 118, figs 6-10.

Athemus (Athemellus) hanatanii - Takahashi 1998: 43.

Lycocerus hanatanii - Okushima 2005: 242, figs 11r, 13u, 15r, 60, 131, 174. — Kazantsev \& Brancucci 2007: 250.

\section{Material examined}

Holotype

JAPAN: ${ }^{\lambda}$, Mt. Omoto-dake, Ishigaki-jima Is., Ryukyus, 1 Mar. 1990, Y. Okushima leg. (KURA).

\section{Other material}

JAPAN: 1 ô, 1 क , Omoto-dake, Ishigaki-jima, Okinawa, Ryukyu, 9 Mar. 1999, T. Kurihara leg. (KURA);

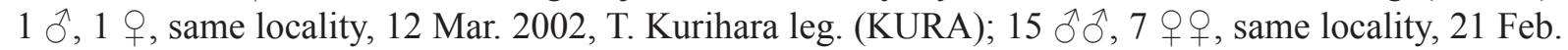

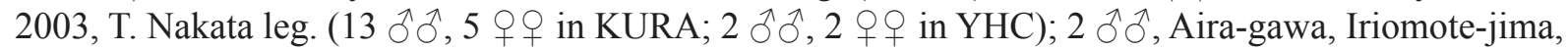
Okinawa, Ryukyu, 14 Mar. 1999, T. Kurihara leg. (KURA).

\section{Description}

See Okushima (1996, 2005).

\section{Distribution}

Japan (Okinawa: Iriomote Island and Ishigaki Island).

Lycocerus ueharaensis (Okushima, 1996)

Athemellus ueharaensis Okushima, 1996: 121, figs 11-14.

Athemus (Athemellus) ueharaensis - Takahashi 1998: 43.

Lycocerus ueharaensis - Okushima 2005: 245, figs 61, 132, 175. — Kazantsev \& Brancucci 2007: 254.

\section{Material examined}

\section{Holotype}

JAPAN: ${ }^{\lambda}$, Mt. Uehara-yama, Iriomote-jima Is., Ryukyus, 11 Mar. 1995, Y. Okushima leg. (KURA).

\section{Other material}

JAPAN: 1 đ, Nakasuji, Ishigaki-jima, Okinawa, Ryukyu, 6 Mar. 1999, T. Kurihara leg. (KURA); 10

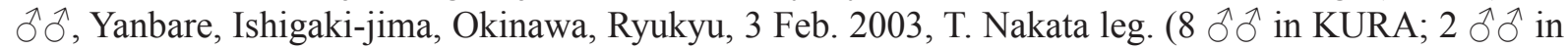
YHC).

\section{Description}

See Okushima $(1996,2005)$. 


\section{Distribution}

Japan (Okinawa: Iriomote Island and Ishigaki Island).

Lycocerus pictus (Wittmer, 1983)

Figs $2 \mathrm{~A}-\mathrm{B}, 3 \mathrm{~A}-\mathrm{C}, 6 \mathrm{~A}-\mathrm{B}, 7$

Athemellus pictus Wittmer, 1983: 170.

Lycocerus pictus - Okushima 2005: 242. — Okushima 2008: 282, fig. 26. — Kazantsev \& Brancucci 2007: 253. — Satô et al. 2015: 51.

\section{Diagnosis}

This species resembles L. yitingi Hsiao \& Okushima sp. nov.; the differential diagnosis is given in Table 2 .

\section{Material examined}

\section{Holotype}

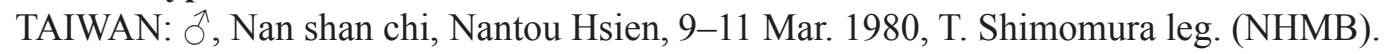

\section{Paratypes}

TAIWAN: 10 ex, same data as for holotype (NHMB).

\section{Other material}

TAIWAN: 15 $ぇ ึ, 7$ 우, Nanshanchi, Nantou, 27 Mar. 1981, H. Yoshimoto leg. (KURA); 1 , Hsileng,

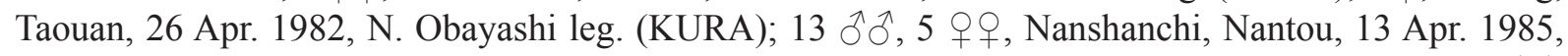

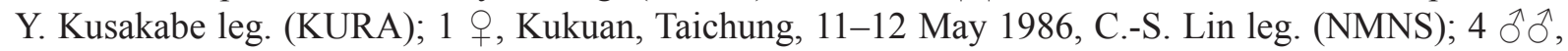
3 우, Nanshanchi, Nantou, 5 Apr. 1988, C. Lou leg. (KURA); 1 J , Baling, Taoyuan, 5 Apr. 1991, Y.

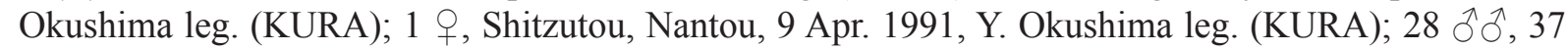
우, Nanshanchi, Nantou, 10 Apr. 1991, Y. Okushima leg. (KURA); 1 ㅅ, 3 우, Kukuan, Taichung, 11 Apr. 1991, Y. Okushima leg. (KURA); 1 9, Shitzutou, Nantou, 12 Apr. 1991, Y. Okushima leg. (KURA); 1 đ̊, Nanshanchi, Nantou, 12 Apr. 1991, K. La leg. (KURA); 4 ô ô, 10 우, Nanshanchi, Nantou, 3 Apr.

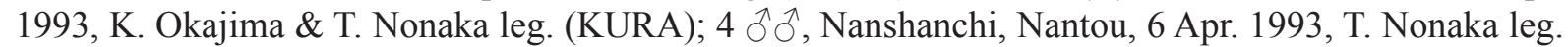
(KURA); 3 우, Wushe, Nantou, 28-29 Apr. 1993, C.-S. Lin \& W.-T. Yang leg. (NMNS); 4 ふึ, 14 우, Lushan Hot Spring, Nantou, 24 Apr. 1994, T. Kishimoto leg. (KURA); 1 ô, Gauvaw [=Luofu],

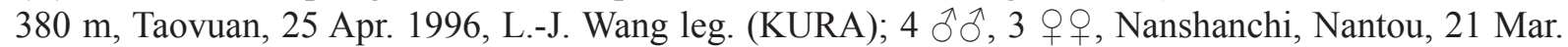
1998, F. Hayashi leg. (KURA); 3 ठ઼ , Chunyang, Nantou, 12 Mar.-9 Apr. 2002, C.-S. Lin \& W.-T. Yang leg. (NMNS); 1 đิ, 1 \%, Nanshanshi, Nantou, 1 Apr. 2012, Y.-T. Wang leg. (YHC); 1 \&, Puli, Nantou,

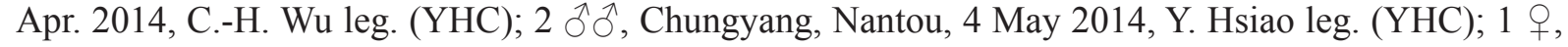
Simashuan Forest Trail, 500m, Miaoli, Y. Hsiao leg. (YHC).

\section{Redescription}

\section{Coloration}

Eyes black. Head dark yellow, with black marking on vertex. Antennae dark yellow or black, with first two or three segments and basal parts of remaining segments dark yellow. Pronotum dark yellow, with black marking in medio-longitudinal part. Elytra completely pale yellow or slightly dark in narrow suture. Legs dark yellow, with apical parts of femora, tibiae and tarsi blackish. Prosternum dark yellow, mesoventrites, metaventrites and abdomen black, with margin of abdominal ventrites and entire abdominal ventrite VII yellowish brown. Body closely covered with fine yellowish pubescence; anterior margin of clypeus fringed with pale bristles; antennae, elytra and legs with some yellowish bristles intermingled with primary pubescence. 
Male (Fig. 2A)

HEAD. Nearly as long as wide; vertex faintly hollowed, depressed along apical margin of clypeus and in lateral areas before eyes; surface densely and finely punctate and semilustrous; anterior margin of clypeus
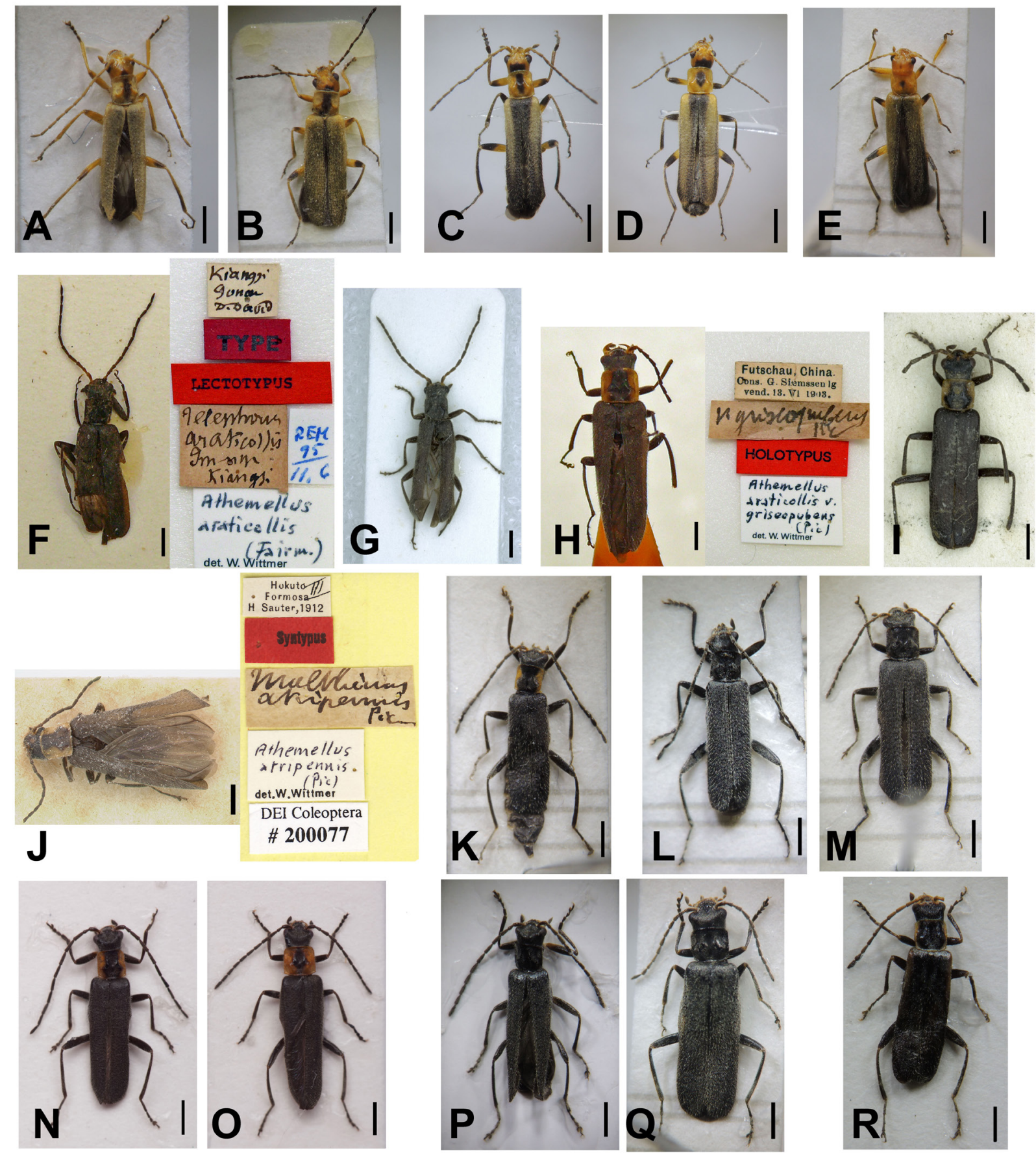

Fig. 2. Habitus, dorsal view. A-B. Lycocerus pictus (Wittmer, 1983). C-E. L. yitingi Hsiao \& Okushima sp. nov. F-G. L. araticollis (Fairmaire, 1897). H-I. L. griseopubens (Pic, 1928). J-M. L. nigripennis (Pic, 1938). N-O. L. aurantiacus Hsiao \& Okushima sp. nov. P-Q. L. evangelium Hsiao \& Okushima sp. nov. R. L. kintaroi Hsiao \& Okushima sp. nov. C, F, H, J, N, P, R. Name-bearing types. D, O, Q. Paratypes. A-B, E, G, I, K-M. Non-type specimens. A, C, F-G, I, K-L, N, P, R. Male. B, D-E, H, J, M, O, Q. Female. Scale bars: $1.0 \mathrm{~mm}$. 
arcuate and faintly indented in middle; eyes not so large, globular and slightly prominent, ratio of eye diameter to interocular space 1:4.4; terminal labial palpomeres rounded ax-shaped; terminal maxillary palpomeres rounded ax-shaped; antennae filiform, extending to elytral midlength; antennomere I clavate, II short and a little expanded apicad, III to XI subcylindrical, all antennomeres without groove, ratio of antennomere lengths: $13: 10: 13: 15: 16: 16: 14: 14: 13.5: 13: 14$.

Pronotum. Subquadrate, slightly narrower than head, nearly as long as wide; anterior and posterior margins moderately arcuate; lateral margins feebly sinuate, slightly diverging posteriorly; anterior angles rounded; posterior angles obtuse; dorsum convex in postero-lateral and hollowed in antero-lateral areas; medio-longitudinal groove distinct in posterior half; surface smooth and semilustrous. Scutellum triangular, with rounded apex.

ELYTRA. Conjointly about 1.4 times as wide as pronotum, about 3.0 times as long as wide, sides subparallel; surface densely and finely punctate and without luster.

LEGs. Moderately slender; femora mostly straight; tibiae mostly straight, with basal part feebly arcuate; claws simple.

Aedeagus (Fig. 3A-C). Ventral process expanded apically, apex curved inwards, basal part broad and extending inwards onto ventral side; dorsal plate of each paramere as long as ventral process, stout and subtruncated, slightly narrowed apically, apical margin with some hairs on it, concave on inner margin. Laterophyse very short, with pointed apex, invisible in lateral view. Inner sac swollen apically, somewhat shorter than tegmen.

Body length 4.00-5.50 mm; width 1.00-1.50 mm.

Female (Fig. 2B)

Similar to male. Body wider than in male. Eyes somewhat smaller than in male, ratio of eye diameter to interocular space 1:4.9. Antennae distinctly shorter than in male, barely exceeding humeri, ratio of antennomere lengths: $13.5: 10: 13: 15: 15: 14: 14: 14: 13: 12: 14$.

Pronotum. Nearly as wide as head, about 1.10 times as long as wide. Elytra conjointly about 1.5 times as wide as pronotum, about 2.6 times as long as wide. Claws simple. Abdominal ventrite VII widely emarginate on each side of terminal margin, forming subtriangular lateral lobes, median lobe moderately developed and triangularly concave in middle, median lobe indistinct in some specimens (Fig. 6A).

Female genitalia (Fig. 6B). Vagina broad and rounded, abruptly extended apically as a long and thick duct; diverticulum and spermathecal duct arising from apex of long duct of vagina; diverticulum moderately thin and spiral; spermathecal duct shorter than diverticulum; spermatheca provided with thin spiral tube, tube longer than diverticulum; accessory gland thin, shorter than spermatheca.

Body length 5.00-6.00 mm; width 1.50-1.75 mm.

\section{Remarks}

Individuals of this species were observed visiting flowers of Lauraceae during the day.

\section{Distribution (Fig. 7)}

Taiwan (endemic). 
HSIAO Y. et al., Revision of the Lycocerus hanatanii species group

Table 2. Diagnostic characters of Lycocerus pictus (Wittmer, 1983) and L. yitingi Hsiao \& Okushima sp. nov.

\begin{tabular}{lcc}
\hline L. pictus & L. yitingi sp. nov. \\
\hline Coloration & $\begin{array}{c}\text { Elytra almost pale yellow, } \\
\text { and smaller black parts on } \\
\text { the vertex and legs }\end{array}$ & $\begin{array}{c}\text { Elytra with large fuscous } \\
\text { area, and larger black parts on } \\
\text { the vertex and legs }\end{array}$ \\
\hline Aedeagus & $\begin{array}{c}\text { Ventral process thicker, laterophyse } \\
\text { with pointed apex, apical margin } \\
\text { of dorsal plate subtruncated }\end{array}$ & $\begin{array}{c}\text { Ventral process thinner, laterophyse } \\
\text { truncated apically, apical margin } \\
\text { of dorsal plate rounded }\end{array}$ \\
\hline Abdominal ventrite & $\begin{array}{c}\text { Mostly yellowish brown } \\
\text { and median lobe } \\
\text { lil of female }\end{array}$ & $\begin{array}{c}\text { Mostly fuscous } \\
\text { less protuberant } \\
\text { more protuberant }\end{array}$ \\
\hline Female genitalia & $\begin{array}{c}\text { Vagina broader and rounded, } \\
\text { spermathecal duct and } \\
\text { accessory gland longer }\end{array}$ & $\begin{array}{c}\text { Vagina stouter, } \\
\text { spermathecal duct and } \\
\text { accessory gland shorter }\end{array}$ \\
\hline
\end{tabular}

Lycocerus yitingi Hsiao \& Okushima sp. nov. urn:1sid:zoobank.org:act:B425500E-BCB5-4BD2-A57A-2AB9CA8700E4

Figs 2C-E, 3D-F, 6C-D, 7

\section{Diagnosis}

This species resembles L. pictus; the differential diagnosis is given in Table 2 .

\section{Etymology}

The specific epithet is dedicated to one of its collectors, Mr. Yi-Ting Chung (Pingtung, Taiwan).

\section{Material examined}

Holotype

TAIWAN: $\widehat{\partial}$, Dahanshan, 1000m, Pingtung, 26 Feb. 2013, Y.-T. Chung leg. (NMNS).

\section{Paratypes}

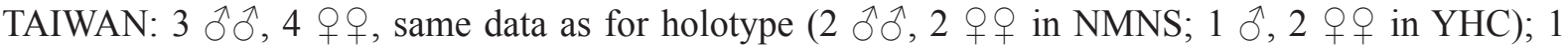

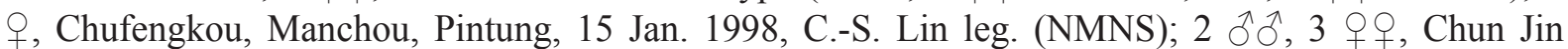
[=Chunrih], 950-1000m, Ping Tung Co., 21 Mar. 2000, C.-L. Li leg. (KURA).

\section{Other material}

TAIWAN: 1 o, 1 q, Chihpen-spa, Peinan Hsiang, Taitung, 5 Apr. 2004, T. Tsuru leg. (KURA); 1 q, Roshan Waterfall, Fuli, Hualien, 16 Feb. 2014, W.-J. Huang leg. (YHC); 2 q $q$, Majia, Pingtung, 12 Mar. 2014, Y.-T. Chung leg. (YHC).

\section{Description}

\section{Coloration}

Eyes black. Head dark yellow, with black marking on vertex. Antennae brownish yellow. Pronotum dark yellow, with black marking in medio-longitudinal part. Elytra fuscous, with wide, pale yellow longitudinal stripe on each elytron. Legs black, with costae, trochanters and basal parts of femora dark yellow; tibiae with dark yellow tinge. Prosternum dark yellow, mesoventritres, metaventrites and abdomen black, with margin of abdominal ventrites pale yellow. Body closely covered with fine 
yellowish pubescence; anterior margin of clypeus fringed with pale bristles; antennae, elytra and legs with some yellowish bristles intermingled with primary pubescence.

Male (Fig. 2C)

HEAD. Nearly as long as wide; vertex faintly hollowed, depressed along apical margin of clypeus and in lateral areas before eyes; surface densely and finely punctate and semilustrous; anterior margin of clypeus
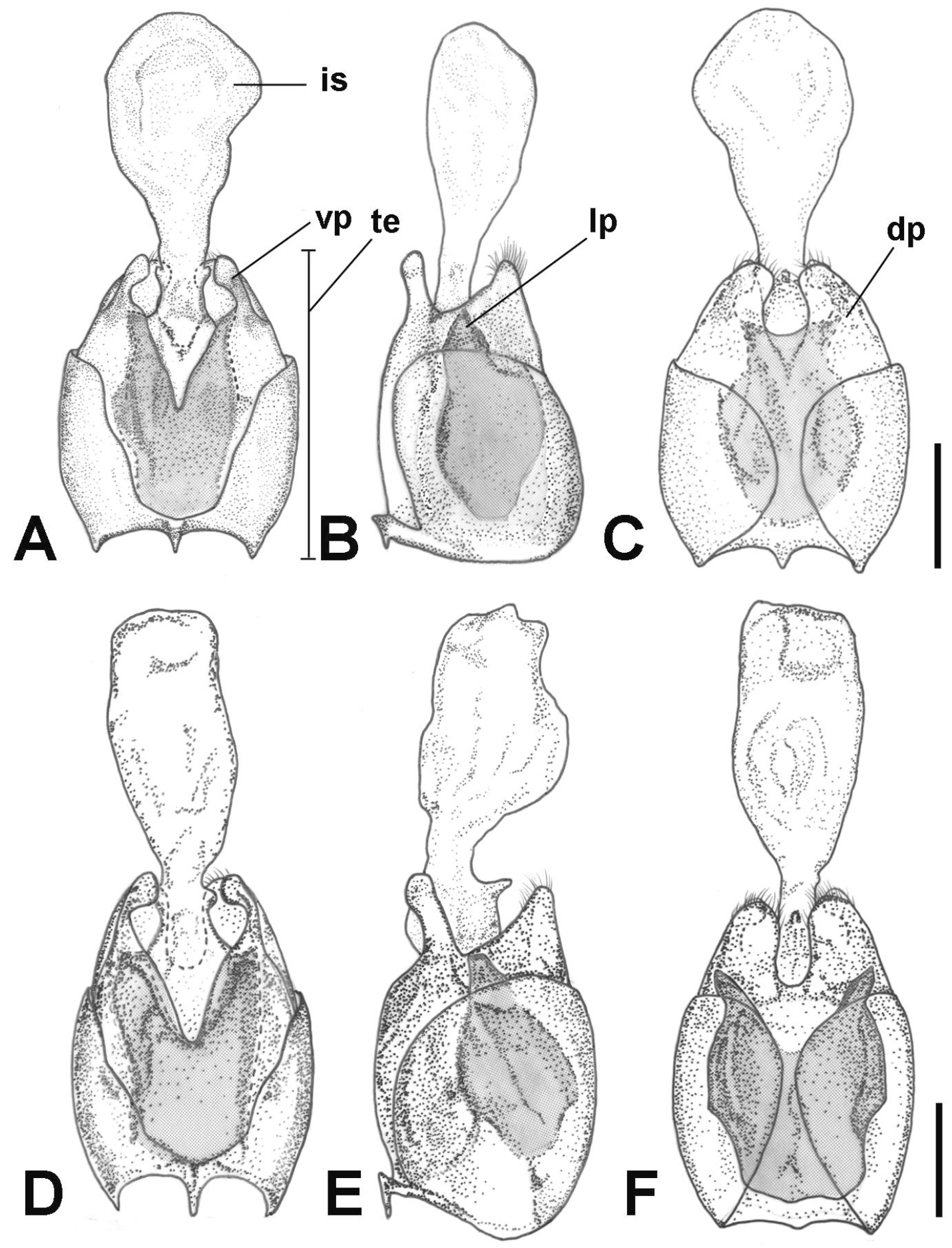

Fig. 3. Aedeagus. A-C. Lycocerus pictus (Wittmer, 1983). D-F. L. yitingi Hsiao \& Okushima sp. nov. A, D. Ventral view. B, E. Lateral view. C, F. Dorsal view. Scale bars: $0.5 \mathrm{~mm}$. 
arcuate and faintly indented in middle; eyes not so large, globular and slightly prominent, ratio of eye diameter to interocular space 1:4.6; terminal labial palpomeres rounded ax-shaped; terminal maxillary palpomeres rounded ax-shaped; antennae filiform, extending to elytral midlength; antennomere I clavate, II short and a little expanded apicad, III to XI subcylindrical, all antennomeres without groove, ratio of antennomere lengths: $11: 10: 12: 16: 16: 16: 15: 15: 14: 13: 14$.

Pronotum. Subquadrate, about 0.90 times as wide as head, about 1.10 times as long as wide; anterior and posterior margins moderately arcuate; lateral margins feebly sinuate, slightly diverging posteriorly; anterior angles rounded; posterior angles obtuse; dorsum convex in postero-lateral and hollowed in anterolateral areas; medio-longitudinal groove distinct in posterior half; surface smooth and semilustrous. Scutellum triangular with rounded apex.

Elytra. Conjointly about 1.5 times as wide as pronotum, about 3.1 times as long as wide, sides subparallel; surface covered with minute grains and without luster.

Legs. Moderately slender; femora mostly straight; tibiae mostly straight, with basal part feebly arcuate; claws simple.

Aedeagus (Fig. 3D-F). Ventral process expanded apically, apex curved inwards, basal part broad and extending inwards onto ventral side; dorsal plate of each paramere as long as ventral process, stout, apical margin rounded, with some hairs on it, concave on inner margin. Laterophyse very short and truncated apically, invisible in lateral view. Inner sac swollen, lengthened behind, and somewhat shorter than tegmen.

Body length 4.95-6.70 mm (holotype: $5.00 \mathrm{~mm})$; width 1.00-1.70 mm $(1.00 \mathrm{~mm})$.

Female (Fig. 2D)

Similar to male. Body wider than in male. Eyes somewhat smaller than in male, ratio of eye diameter to interocular space 1:5.1. Antennae distinctly shorter than in male, barely exceeding humeri, ratio of antennomere lengths: $11: 10: 11: 13: 13: 13: 12: 12: 11: 10: 12$.

Pronotum. Nearly as wide as head, slightly longer than width. Elytra conjointly about 1.5 times as wide as pronotum, about 2.9 times as long as wide. Claws simple. Abdominal ventrite VII widely emarginate on each side of terminal margin, forming subtriangular lateral lobes, median lobe moderately developed and triangularly concave in middle (Fig. 6C).

Female Genitalia (Fig. 6D). Vagina stout and abruptly extended apically as a long and thick duct; diverticulum and spermathecal duct arising from apex of long duct of vagina; diverticulum moderately thin and spiral; spermathecal duct shorter than diverticulum; spermatheca provided with a thin spiral tube, tube longer than diverticulum; accessory gland thin, shorter than spermatheca.

Body length $6.00-7.50 \mathrm{~mm}$; width $1.30-1.80 \mathrm{~mm}$.

\section{Remarks}

Several examined specimens listed as other material were different from the type by having the head, antennae, thorax, basal half of the femora and tibiae orange yellow; the black markings on the vertex, pronotum and legs smaller or indistinct; elytra mostly dark yellow, with suture and lateral sides narrowly black (Fig. 2E), but display no distinct differences compared to the type specimens on the structure of the aedeagus. Because insufficient materials were available and distinct diagnostic characters were not discovered, we herein prefer to regard these specimens as representing a color variation of $L$. yitingi sp. nov. rather than giving it a new taxonomic status. Nevertheless, we choose not to place these 

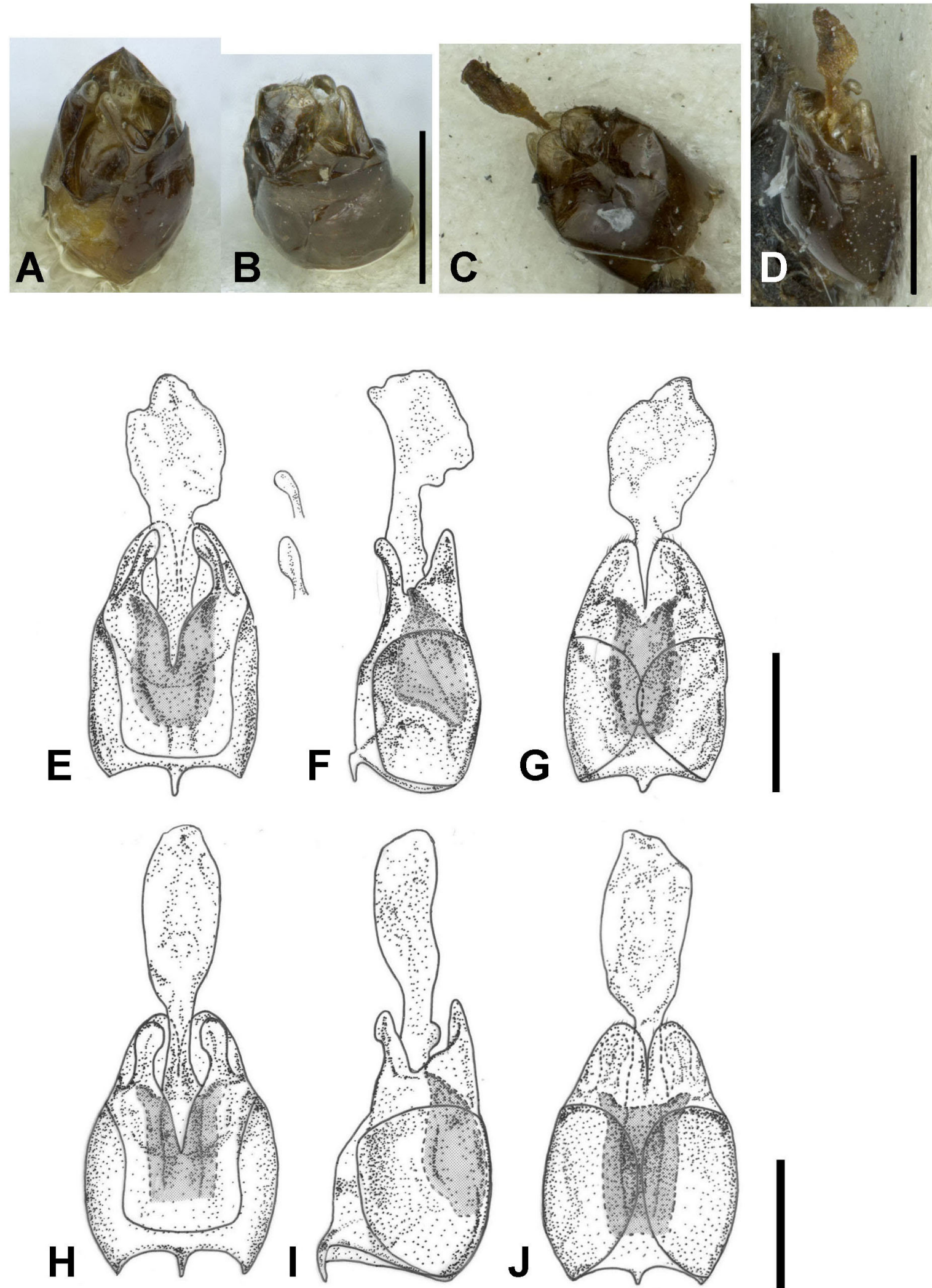

Fig. 4. Aedeagus. A-B. Lycocerus araticollis (Fairmaire, 1897). C-D. L. griseopubens (Pic, 1928). E-G. L. nigripennis (Pic, 1938). H-J. L. aurantiacus Hsiao \& Okushima sp. nov. A. Ventrolateral view. B. Dorsolateral view. E, H. Ventral view. D, F, I. Lateral view. C, G, J. Dorsal view. Scale bars: $0.5 \mathrm{~mm}$. 
specimens among the paratypes because they will possibly be confirmed as a new taxon in the future after more material is examined.

\section{Distribution (Fig. 7)}

Taiwan (endemic).

Lycocerus araticollis (Fairmaire, 1897)

Figs $2 \mathrm{~F}-\mathrm{G}, 4 \mathrm{~A}-\mathrm{B}$

Telephorus araticollis Fairmaire, 1897: 216.

Cantharis araticollis - Delkeskamp 1977: 62. — Kazantsev \& Brancucci 2007: 239.

Lycocerus araticollis - Okushima 2007b: 257, fig. 1.

\section{Diagnosis}

This species resembles the nearly black forms of L. nigripennis and L. evangelium Hsiao \& Okushima sp. nov.; the differential diagnosis is given in Table 3.

\section{Material examined}

\section{Lectotype}

CHINA: ô (MNHN): [h] Kiangsi [=Jiangxi] / Gonon / D. David // [p] TYPE // [p] LECTOTYPUS // [h] Telephorus / araticollis / Fairm / Kiangsi [=Jiangxi] // [h] REM / 95 / $11.6 / /[\mathrm{h}]$ Athemellus / araticollis / (Fairm.) / [p] det. W. Wittmer.

\section{Other material}

CHINA: 1 §ै, Taichow, 19 Apr. 1935, collector unknown (NHMB).

\section{Note}

The locality of the additional material possibly referred to Taizhou, but there are two localities in China named Taizhou in Zhejiang and Jiangsu, respectively.

\section{Description}

See Okushima (2007b).

\section{Supplementary description}

AedeAgus (Fig. 4A-B). Ventral process expanded and rounded apically, apex curved inwards, basal part broad and extending inwards onto ventral side; dorsal plate of each paramere somewhat longer than ventral process, protuberant, apical margin truncated, with some hairs on it. Laterophyse very short and slender, with pointed apex, barely visible in lateral view.

\section{Remarks}

This species should be attributed to $L$. hanatanii species group because its morphological characteristics match the definition of this species group, in agreement with the cladogram (Fig. 9), although the female genitalia have not been examined.

\section{Distribution}

China (Jiangxi Province). 
Lycocerus griseopubens (Pic, 1928)

Figs $2 \mathrm{H}-\mathrm{I}, 4 \mathrm{C}-\mathrm{D}$

Malthinus atripennis var. griseopubens Pic, 1928: 55.

Malthinus nigripennis var. griseopubens - Delkeskamp 1977: 354.

Lycocerus atripennis - Kazantsev 2007: 48. - Kazantsev \& Brancucci 2007: 249.

Lycocerus griseopubens - Okushima 2007b: 259, figs 2, 6.

\section{Diagnosis}

This species resembles the yellowish brown pronotum forms of L. nigripennis and L. aurantiacus Hsiao \& Okushima sp. nov.; the differential diagnosis is given in Table 3.

\section{Material examined}

\section{Holotype}

CHINA: o (MNHN): [p] Futschau [=Fuzhou], China / Cos. G. Siemssen lg / vend. 13. VI 1903. // [h] var. griseopubens / Pic // [p] HOLOTYPUS // [h] Athemellus / araticollis / griseopubens / (Pic) / [p] det. W. Wittmer.

\section{Other material}

CHINA: 1 ô, 1 , Fiuchou [=Fuzhou], Fujian, date and collector unknown (NHMB).

\section{Description}

See Okushima (2007b).

\section{Supplementary description}

Male (Fig. 2I)

Similar to female (= holotype). Body narrower than in female. Eyes somewhat larger than in female, ratio of eye diameter to interocular space 1:4.5. Antennomeres IV to VII longer than in female, VIII to XI unavailable, ratio of antennomere lengths: $15: 10: 12: 15: 15: 15: 12:-:-:-:-$.

Pronotum. About 0.95 times as wide as head, nearly as long as wide. Elytra conjointly about 1.6 times as wide as pronotum, about 2.8 times as long as wide. Legs moderately slender; femora mostly straight; tibiae mostly straight, with basal part feebly arcuate; claws simple.

Aedeagus (Fig. 4C-D). Ventral process moderately expanded and rounded apically, apex curved inwards, basal part broad and extending inwards onto ventral side; dorsal plate of each paramere as long as ventral process, broad, apical margin rounded, with some hairs on it. Laterophyse very short, invisible in lateral view. Inner sac swollen, shorter than tegmen.

\section{Remarks}

This species should be attributed to the $L$. hanatanii species group as its morphological characteristics match the definition of this species group, in agreement with the cladogram (Fig. 9); however, the female genitalia remain unexamined.

\section{Distribution}

China (Fujian Province). 

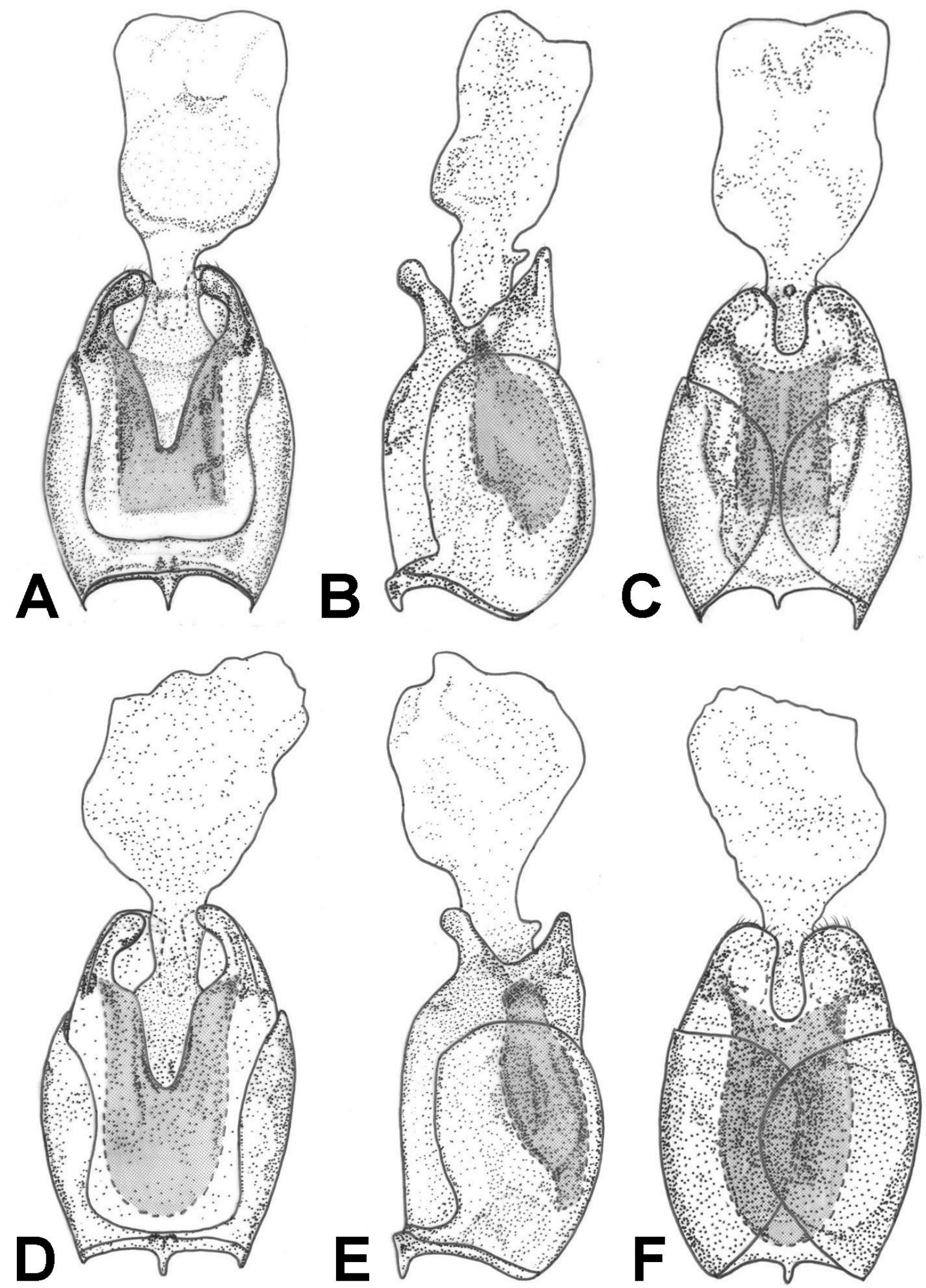

Fig. 5. Aedeagus. A-C. Lycocerus evangelium Hsiao \& Okushima sp. nov. D-F. L. kintaroi Hsiao \& Okushima sp. nov. A, D. Ventral view. B, E. Lateral view. C, F. Dorsal view. Scale bars: $0.5 \mathrm{~mm}$. 
Table 3. Diagnostic characters of L. nigripennis (Pic, 1938) and similar species.

\begin{tabular}{|c|c|c|c|c|c|}
\hline & L. araticollis & L. griseopubens & L. nigripennis & $\begin{array}{l}\text { L. aurantiacus } \\
\text { sp. nov. }\end{array}$ & $\begin{array}{l}\text { L. evangelium } \\
\text { sp. nov. }\end{array}$ \\
\hline $\begin{array}{l}\text { Antennomeres } \\
\text { in males }\end{array}$ & Shorter & Shorter & More elongated & More elongated & Shorter \\
\hline $\begin{array}{l}\text { Coloration of } \\
\text { pronotum }\end{array}$ & Black & $\begin{array}{c}\text { Orange, with a } \\
\text { black marking in } \\
\text { middle }\end{array}$ & $\begin{array}{l}\text { Black or orange } \\
\text { to yellowish } \\
\text { brown, with a } \\
\text { black marking } \\
\text { in middle }\end{array}$ & $\begin{array}{l}\text { Orange, with a } \\
\text { black marking in } \\
\text { middle }\end{array}$ & Black \\
\hline $\begin{array}{l}\text { Surface of } \\
\text { elytra }\end{array}$ & Lusterless & Lusterless & Semilustrous & Semilustrous & $\begin{array}{l}\text { Moderately } \\
\text { lustrous }\end{array}$ \\
\hline $\begin{array}{l}\text { Convexity on } \\
\text { the pronotum }\end{array}$ & Less angular & Less angular & Angular & Angular & Angular \\
\hline $\begin{array}{l}\text { Pubescence on } \\
\text { the elytra }\end{array}$ & Slightly sparser & Slightly sparser & Slightly sparser & Slightly sparser & Slightly denser \\
\hline $\begin{array}{l}\text { Ventral process } \\
\text { of aedeagus }\end{array}$ & $\begin{array}{l}\text { Moderate and } \\
\text { expanded } \\
\text { apically, the } \\
\text { apex curved } \\
\text { inwards }\end{array}$ & $\begin{array}{l}\text { Moderate and } \\
\text { expanded } \\
\text { apically, the } \\
\text { apex curved } \\
\text { inwards }\end{array}$ & $\begin{array}{l}\text { Moderate and } \\
\text { expanded } \\
\text { apically, the } \\
\text { apex curved } \\
\text { inwards }\end{array}$ & $\begin{array}{c}\text { Thick and } \\
\text { strongly } \\
\text { expanded } \\
\text { apically, the apex } \\
\text { slightly curved } \\
\text { inwards }\end{array}$ & $\begin{array}{l}\text { Moderate and } \\
\text { expanded } \\
\text { apically, the } \\
\text { apex curved } \\
\text { inwards }\end{array}$ \\
\hline $\begin{array}{l}\text { Dorsal plate of } \\
\text { aedeagus }\end{array}$ & $\begin{array}{l}\text { Protuberant, } \\
\text { somewhat } \\
\text { longer than } \\
\text { ventral } \\
\text { process, the } \\
\text { apical margin } \\
\text { truncated }\end{array}$ & $\begin{array}{l}\text { Broad, as long } \\
\text { as ventral } \\
\text { process, the } \\
\text { apical margin } \\
\text { rounded }\end{array}$ & $\begin{array}{l}\text { Protuberant } \\
\text { and narrowed } \\
\text { apically, } \\
\text { somewhat } \\
\text { longer than } \\
\text { ventral process, } \\
\text { the apical } \\
\text { margin rounded }\end{array}$ & $\begin{array}{c}\text { Protuberant } \\
\text { and narrowed } \\
\text { apically, slightly } \\
\text { longer than } \\
\text { ventral process, } \\
\text { the apical margin } \\
\text { rounded }\end{array}$ & $\begin{array}{l}\text { Broad, as long } \\
\text { as ventral } \\
\text { process, the } \\
\text { apical margin } \\
\text { rounded, and } \\
\text { concave on } \\
\text { inner margin }\end{array}$ \\
\hline
\end{tabular}

\section{Lycocerus nigripennis (Pic, 1938)}

Figs $2 \mathrm{~J}-\mathrm{M}, 4 \mathrm{E}-\mathrm{G}, 6 \mathrm{E}-\mathrm{F}, 8$

Malthinus atripennis Pic, 1922: 30.

Malthinus nigripennis Pic, 1938: 121 [new name for Malthinus atripennis Pic, 1922].

Podabrinus taihokuensis Wittmer, 1954: 276.

Athemellus taihokuensis - Wittmer 1972: 126, fig. 1.

Athemellus atripennis - Wittmer 1983: 168.

Lycocerus atripennis - Kazantsev \& Brancucci 2007: 249.

Lycocerus nigripennis - Okushima 2007b: 260; 2008: 282, fig. 25. — Satô et al. 2015: 51.

\section{Diagnosis}

The nearly black form of this species resembles L. araticollis and L. evangelium Hsiao \& Okushima sp. nov., and the yellowish brown pronotum form resembles L. griseopubens and L. aurantiacus Hsiao \& Okushima sp. nov.; the differential diagnosis is given in Table 3. 

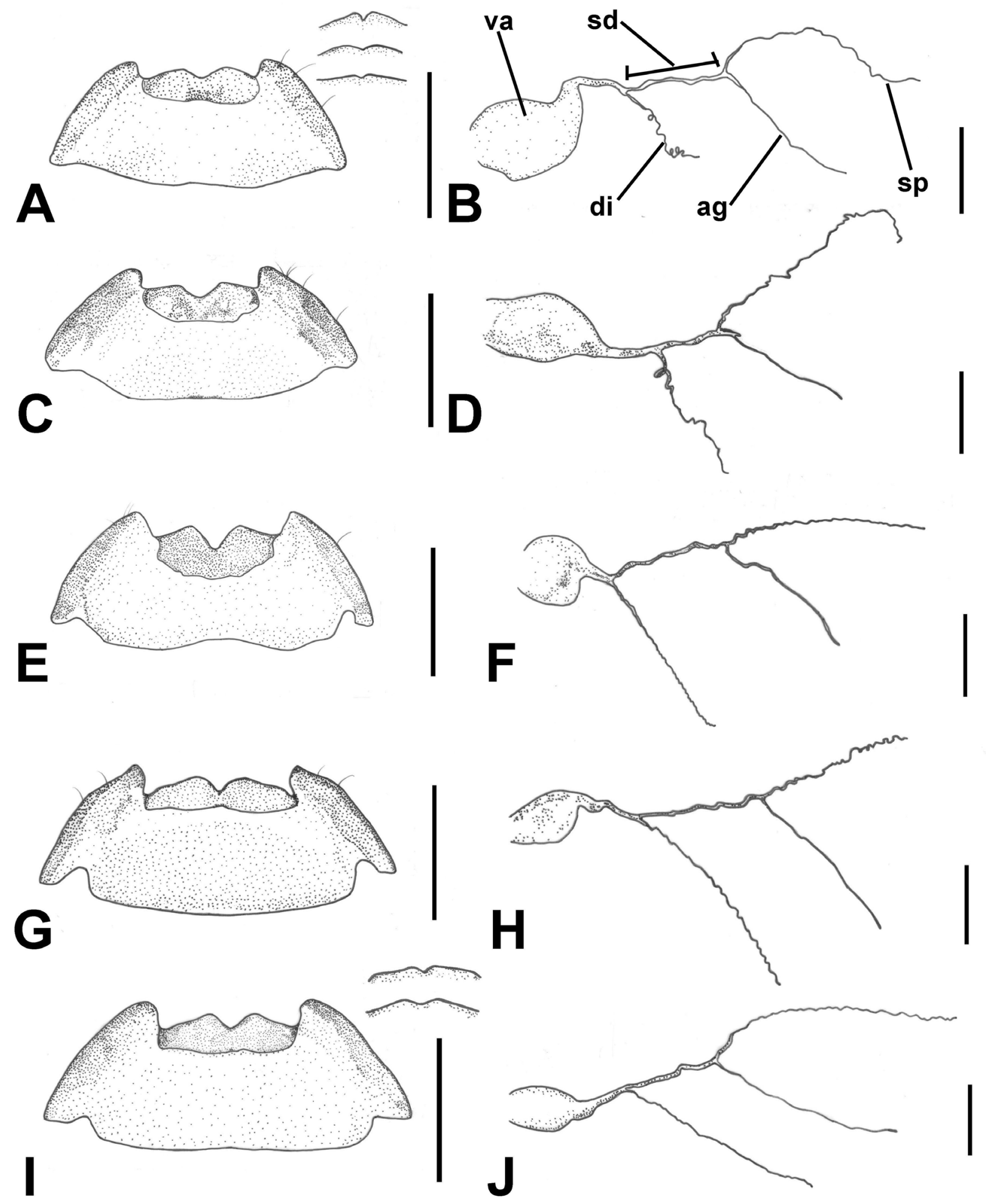

Fig. 6. A-B. Lycocerus pictus (Wittmer, 1983). C-D. L. yitingi Hsiao \& Okushima sp. nov. E-F. L. nigripennis (Pic, 1938). G-H. L. aurantiacus Hsiao \& Okushima sp. nov. I-J. L. evangelium Hsiao \& Okushima sp. nov. A, C, E, G, I. Abdominal ventrite VII of female. B, D, F, H, J. Female genitalia, lateral view. Scale bars: A, C, E, G, I = $1.0 \mathrm{~mm}$; B, D, F, H, J = $0.5 \mathrm{~mm}$. 


\section{Material examined}

\section{Syntype of Malthinus atripennis Pic, 1922}

TAIWAN: $q$ (SDEI): [p] Hokuto / [h] III / [p] Formosa / H. Sauter, 1912 // [p] Syntypus // [h] Malthinus / atripennis / Pic // [h] Athemellus / atripennis / (Pic) / [p] det. W. Wittmer // [p] DEI Coleoptera / \# 200077. [Note: This female syntype of M. atripennis is possibly the female holotype which Wittmer (1983) referred to.]

\section{Holotype of Podabrinus taihokuensis Wittmer, 1954}

TAIWAN: O (CAS): [p] Taihoku / Formosa / [h] III-27-32 // [p] L. Gressitt / Collection // [p] L. Gressitt Collector // [h] Holototypus // [h] Podabrinus / taihokuensis / Wittmer / [p] det. W. Wittmer // [p] California Academy of Sciences / Type No. [h] 7787.

\section{Paratype of Podabrinus taihokuensis Wittmer, 1954}

TAIWAN: ठ (NHMB): [h] A. / taihokuensis / (Wittmer) / [p] det. W. Wittmer // [h] P. / taihokuensis / Wittmer / [p] det. W. Wittmer // [h] Athemellus / atripennis / (Pic) / [p] det. W. Wittmer // [p] Paratypus // [p] Taihoku / Formosa / [h] III-27-32 // [h] 37 // [p] L. Gressitt / Collection // [p] Naturhistorisches / Museum Basel / Coll. W. Wittmer // [p] CANTHARIDAE / CANTH00003105.

\section{Other material}

TAIWAN: $2 \widehat{\jmath} \widehat{\jmath}$, Junhua, Taoyuan, 11 Mar. 1972, B.-S. Chang leg. (NMNS); 1 q, Bajie [=Baigi], Taoyuan, 11 Mar. 1972, B.-S. Chang leg. (NMNS); 1 q, Hsileng, Taoyuan Hsien, 2 Apr. 1982, N. Ohbayashi leg. (EUMJ); 2 §ð, Lushan spa, Nantou Hsien, 2 May 1982, N. Ohbayashi leg. (KURA); 1 q, Fukukoo, Toen-ken [=Taoyuan], 28 Jan. 1983, K. Baba leg. (EUMJ); 1 ô, Tam Shui, N Taiwan, 20 Feb. 1987, K. Baba leg. (EUMJ); 1 ðૈ, Sun Moon Lake, 1000 m, M Taiwan, 14 Mar. 1989, K. Baba leg. (EUMJ); 2 §̊, 1 q, Mu-Tsar, Taipei, 9 Feb. 1991, C.-L. Li leg. (KURA); 1 , , Baling, Taoyuan Hsien, 5-8 Apr. 1991, T. Kishimoto leg. (KURA); 1 ภ, 2 우, Nanshanchi, Nantou Hsien, 10 Apr. 1991, Y. Okushima leg. (KURA); 1 क, Fuhsing, Taoyuan, 30 Mar. 1992, I.-S. Hsu leg. (NMNS); 1 §, 1 , Wanjung, Hualien, 2 Feb. 1992, C.-Y. Lee leg. (NMNS); 2 ภ, 3 우, Yangmingshan, Taipei, 27 Mar. 1993, T. Nonaka leg. (KURA); 2 우, Lushan spa, Nantou Hsien, 24 Apr. 1994, T. Kishimoto leg. (KURA); 1 q, Chikou, 350m, Taoyuan Hsien, 25 Apr. 1996, L.-J. Wang leg. (KURA); 1 ô, 1 q, Fushan, 21 Mar. 1998, M. Satô leg. (KURA); 7 우, Paling, Taoyuan, 31 Mar. 1998, M. Satô leg. (KURA); 1 ภ, Lushan, Nantou, 2 Apr. 1998, F. Hayashi leg. (KURA); 4 $\partial^{\lambda}, 2$ q $q$, Gauvaw [=Luofu], 380 m, Taovuan, 25 Apr. 1998, L.-J. Wang leg. (KURA); 2 ふै ${ }^{\lambda}$, Chunyang, Jenai, Nantou, 8-10 Mar.

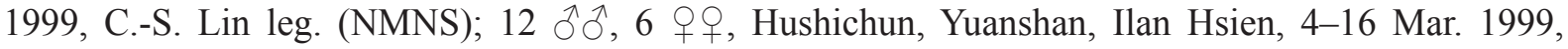
T. Mizusawa leg. (KURA); 7 $\widehat{\partial}, 1$ q, Yuanshan, Ilan Hsien, 23 Mar. 2000, T. Mizusawa leg. (KURA);

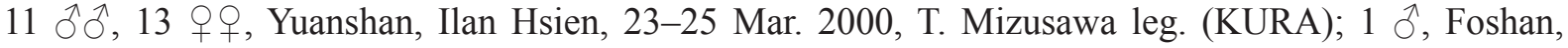
Sanxia, Taipei, 27 Apr. 2009, S.-H. Chang leg. (YHC); 1 ㅇ, Baishihu, Neihu, Taipei, 14 Feb. 2013,

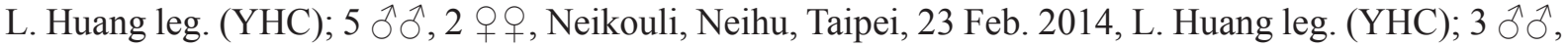
1 q, Shuanchiyen, Taipei, 7 Mar. 2014, L. Huang leg. (YHC); 1 , Fuchushan, Taipei, 25 Mar. 2014, C.-J. Li leg. (YHC); 1 \&, Baehengonlu [=Northern Cross Island Highway], 9 Apr. 2014, L. Huang leg. (YHC); 1 + , Fushan, Taipei, 24 May 2014, L. Huang leg. (YHC); 1 ô, Fuchushan, Taipei, 27 Feb. 2015,

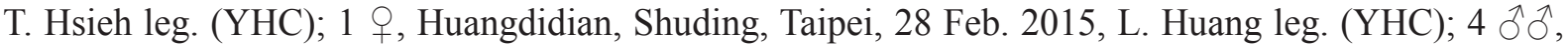
6 우, Kantoushan, Tainan, 28 Feb. 2015, W.-C. Liao leg. (YHC); $3 \hat{\jmath} \widehat{\jmath}, 4$ 웅, Xankonchuan, Danshui, Taipei, Y.-J. Lu leg. (YHC); 1 + , Shanming, Taoyuan, 14 Mar. 2015, Y. Hsiao leg. (YHC).

\section{Redescription}

\section{Coloration}

Eyes black. Head black, but brown in frons. Antennae black, with yellow tinge in the first two segments. Mandibles yellowish brown. Pronotum yellowish brown to orange, with a black marking in mediolongitudinal part. Elytra black. Legs black, with coxae more or less yellowish brown. Prosternum 
yellowish brown; mesoventrites, metaventrites and abdomen black. Body closely covered with pale pubescence; anterior margin of clypeus, antennae, elytra and legs fringed with pale bristles.

Male (Fig. 2K-L)

HEAD. Nearly as long as wide; vertex faintly hollowed, depressed along apical margin of clypeus and in lateral areas before eyes; surface densely and finely punctate and semilustrous; anterior margin of

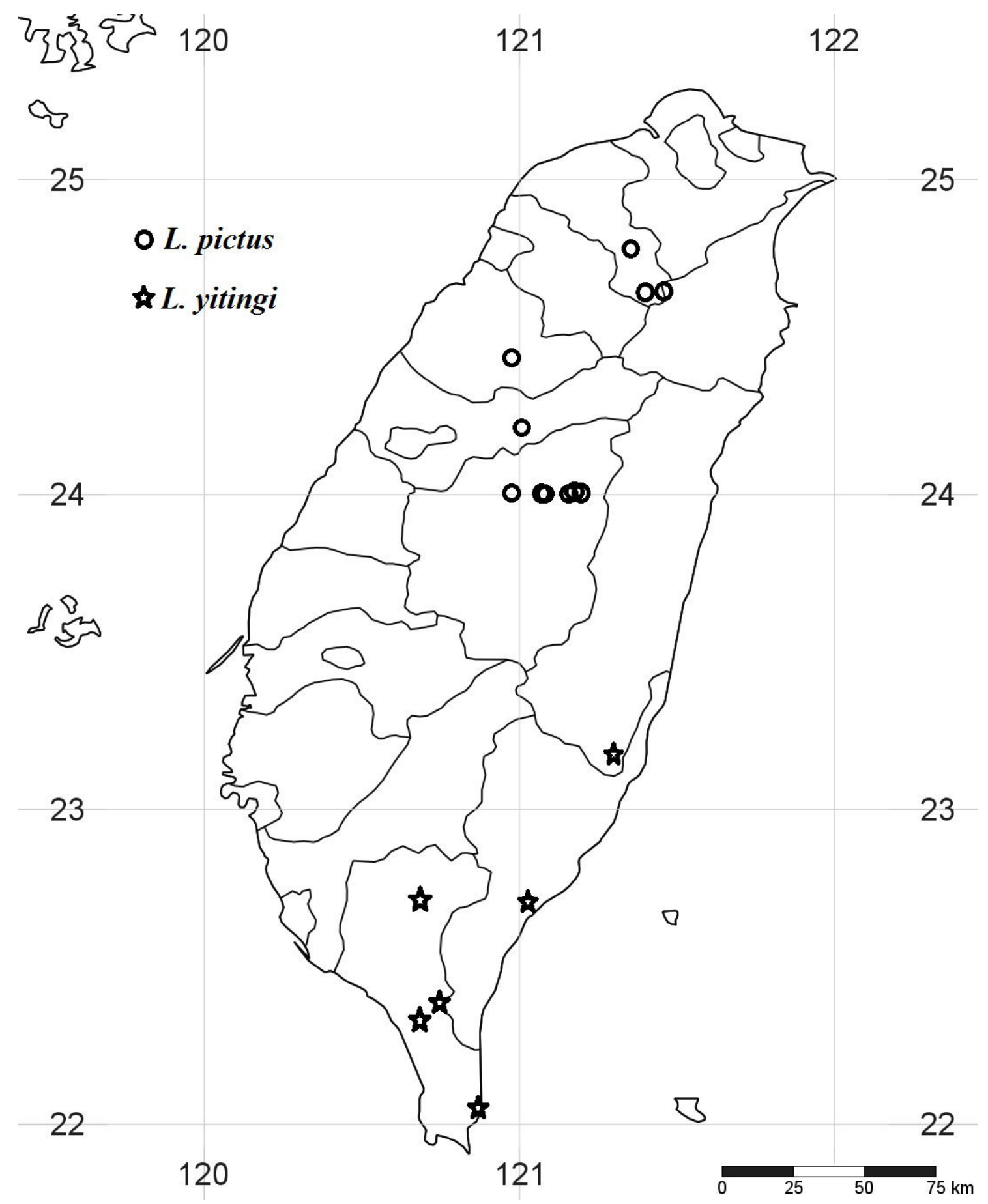

Fig. 7. Distribution map of Lycocerus pictus (Wittmer, 1983) and L. yitingi Hsiao \& Okushima sp. nov. from Taiwan. 
clypeus arcuate and faintly indented in middle; eyes not so large, globular and slightly prominent, ratio of eye diameter to interocular space 1:4.0; terminal labial palpomeres rounded ax-shaped; terminal maxillary palpomeres rounded ax-shaped; antennae filiform, somewhat exceeding elytral midlength; antennomere I clavate, II short and a little expanded apicad, III to XI subcylindrical, all antennomeres without groove, ratio of antennomere lengths: $15: 10: 14.5: 17.5: 17.5: 17.5: 17: 16: 15.5: 15: 16.5$.

Pronotum. Subquadrate, about 0.90 times as wide as head, slightly longer than width; anterior and posterior margins moderately arcuate; lateral margins feebly sinuate, slightly diverging posteriorly; anterior angles rounded; posterior angles obtuse; dorsum convex in postero-lateral and hollowed in antero-lateral areas; medio-longitudinal groove distinct in posterior half; surface smooth and semilustrous. Scutellum triangular, with rounded apex.

ELYTRA. Conjointly about 1.6 times as wide as pronotum, about 2.9 times as long as wide, sides subparallel; surface densely and finely punctate and semilustrous.

LEGs. Moderately slender; femora mostly straight; tibiae mostly straight, with basal part feebly arcuate; claws simple.

Aedeagus (Fig. 4E-G). Ventral process expanded apically, apex strongly or moderately expanded, apex curved inwards, basal part broad and extending inwards onto ventral side; dorsal plate of each paramere somewhat longer than ventral process, protuberant and narrowed apically, apical margin rounded, with some hairs on it. Laterophyse very short, with rounded apex, barely visible in lateral view. Inner sac swollen, lengthened behind, and shorter than tegmen.

Body length 4.80-6.70 mm; width 1.15-2.30 mm.

Female (Fig. 2J, M)

Similar to male. Body wider than in male. Eyes somewhat smaller than in male, ratio of eye diameter to interocular space 1:4.8. Antennae distinctly shorter than in male, barely exceeding humeri, ratio of antennomere lengths: $12: 10: 11.5: 12.5: 12: 13: 12: 11.5: 11: 10: 12$.

Pronotum. Nearly as wide as head, nearly as long as wide. Elytra conjointly about 1.6 times as wide as pronotum, about 3.1 times as long as wide. Abdominal ventrite VII widely emarginate on each side of terminal margin, forming subtriangular lateral lobes, median lobe considerably developed and triangularly concave in middle (Fig. 6E).

Female genitalia (Fig. 6F). Vagina rounded, abruptly extended apically as a long and thick duct; diverticulum and spermathecal duct arising from apex of long duct of vagina; diverticulum moderately thin and spiral, longer than spermathecal duct; spermatheca provided with thin spiral tube, tube nearly as long as diverticulum; accessory gland thin, shorter than spermatheca.

Body length $6.10-7.00 \mathrm{~mm}$; width $1.30-1.80 \mathrm{~mm}$.

\section{Variation}

Body nearly black, including pronotum.

\section{Remarks}

This species is widely distributed in low-altitude forest in Taiwan and appears mainly in the spring according to the label data. It was observed visiting flowers of Machilus thunbergii Siebold \& Zucc. (Lauraceae) during the day. Additionally, during our study of the collections of different institutions and the survey of the first author's personal field trip, the nearly black pronotum form was found to be typical 
of this species, although all of the type specimens including those of Malthinus atripennis Pic, 1922 and Podabrinus taihokuensis Wittmer, 1954 represent the yellowish fringed pronotum form.

Distribution (Fig. 8)

Taiwan (endemic).

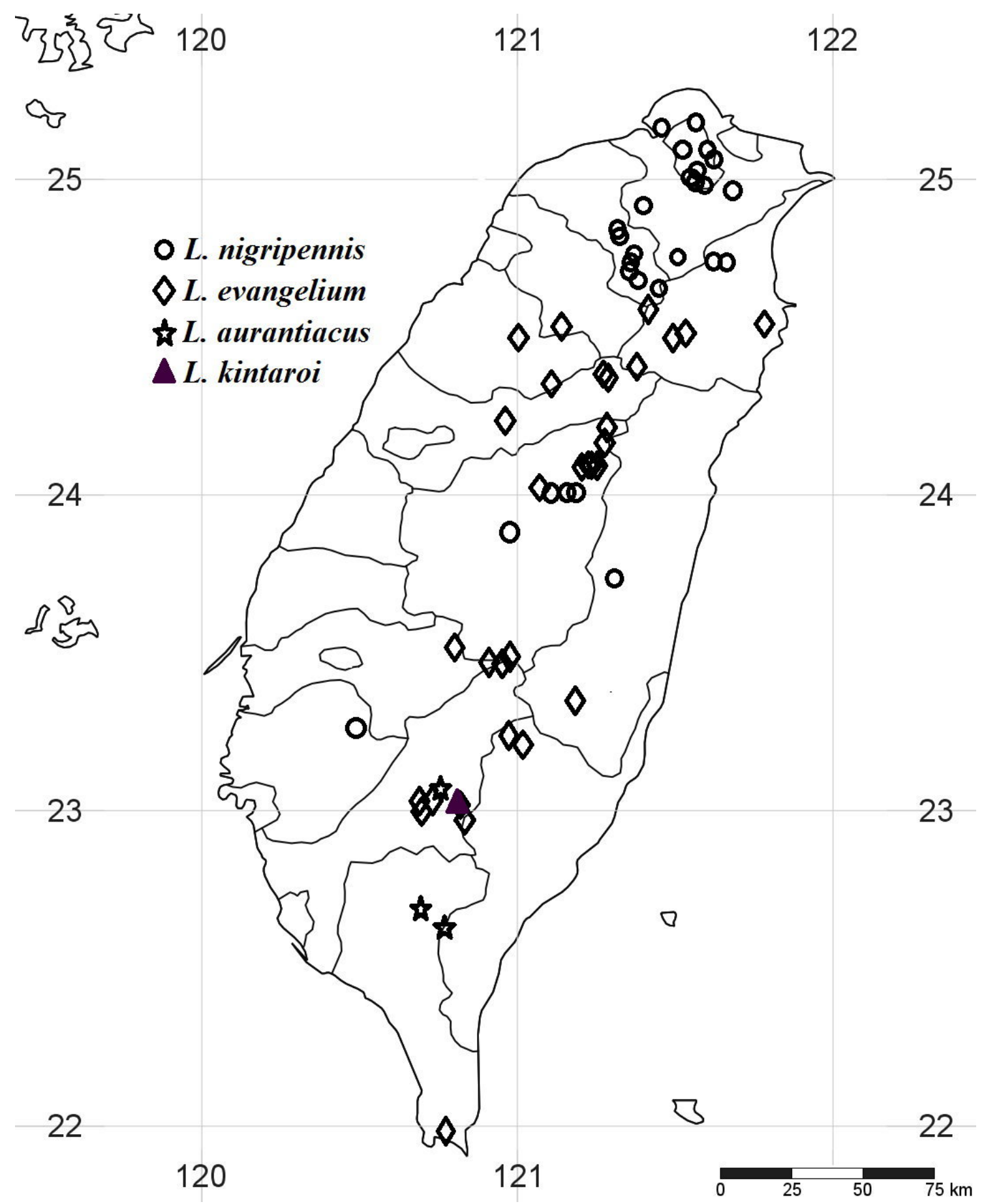

Fig. 8. Distribution map of L. nigripennis (Pic, 1938), L. evangelium Hsiao \& Okushima sp. nov., L. aurantiacus Hsiao \& Okushima sp. nov. and L. kintaroi Hsiao \& Okushima sp. nov. from Taiwan. 
Lycocerus aurantiacus Hsiao \& Okushima sp. nov. urn:1sid:zoobank.org:act:1CD64F32-4749-48C6-80CF-C8981514E12B

Figs $2 \mathrm{~N}-\mathrm{O}, 4 \mathrm{H}-\mathrm{J}, 6 \mathrm{G}-\mathrm{H}, 8$

\section{Diagnosis}

This species resembles L. griseopubens and the yellowish brown pronotum form of L. nigripennis; the differential diagnosis is given in Table 3 .

\section{Etymology}

The specific epithet is derived from the Latin aurantiacus ("orange"), referring to its orange fringed pronotum.

\section{Type material}

\section{Holotype}

TAIWAN: ग̃र, Majia Township, 900 m, Pingtung, 12 Mar. 2014, Y.-T. Chung leg. (NMNS).

\section{Paratypes}

TAIWAN: $9 \widehat{\partial}, 9$ 우, same data as for holotype (5 $\widehat{\partial}, 5$ 우 0 in NMNS; $2 \hat{\jmath}, 2$ 우 in TARI; $2 \hat{\jmath}$, 2 우 in YHC); 1 ㅅ, 1 으, Tengchih, Taoyuan, Kaohsiung Hsien, 29 Mar.-1 Apr. 2001, S. Nagashima leg. (KURA); 1 \&, Baedawushan [=North Dawushan], Pingtung, 2 Apr. 2013, R.-H. Liou leg. (YHC);

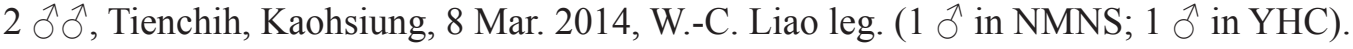

\section{Description}

\section{Coloration}

Eyes and head black. Antennae black, with yellow tinge at base of first segment. Mandibles yellowish brown. Pronotum orange, with black marking in medio-longitudinal part. Elytra black. Legs black. Pro-, meso- and metasterna, as well as abdomen black, with margins of abdominal ventrites yellowish brown. Body closely covered with pale pubescence; anterior margin of clypeus, antennae, elytra and legs fringed with pale bristles.

Male (Fig. 2N)

HEAD. Nearly as long as wide; vertex faintly hollowed, depressed along apical margin of clypeus and in lateral areas before eyes; surface densely and finely punctate and semilustrous; anterior margin of clypeus arcuate and faintly indented in middle; eyes not so large, globular and slightly prominent, ratio of eye diameter to interocular space 1:5.3; terminal labial palpomeres rounded ax-shaped; terminal maxillary palpomeres rounded ax-shaped; antennae filiform, barely exceeding elytral midlength; antennomere I clavate, II short and a little expanded apicad, III to XI subcylindrical, all antennomeres without groove, ratio of antennomere lengths: $16: 10: 18: 21: 21: 20: 20: 20: 19: 17: 19$.

Pronotum. Subquadrate, about 0.90 times as wide as head, slightly longer than width; anterior and posterior margins moderately arcuate; lateral margins feebly sinuate, slightly diverging posteriorly; anterior angles rounded; posterior angles obtuse; dorsum convex in postero-lateral and hollowed in antero-lateral areas; medio-longitudinal groove distinct in posterior half; surface smooth and semilustrous. Scutellum triangular with rounded apex.

ELYTRA. Conjointly about 1.5 times as wide as pronotum, about 3.0 times as long as wide, sides subparallel; surface densely and finely punctate and semilustrous.

LEGs. Moderately slender; femora mostly straight; tibiae mostly straight, with basal part feebly arcuate; claws simple. 
Aedeagus (Fig. 4H-J). Ventral process thick, strongly expanded and rounded apically, apex moderately curved inwards, basal part broad and extending inwards onto ventral side; dorsal plate of each paramere slightly longer than ventral process, protuberant and narrowed apically, apical margin rounded, with some hairs on it. Laterophyse very short, with pointed apex, invisible in lateral view. Inner sac swollen, lengthened behind, somewhat shorter than tegmen.

Body length 5.00-6.00 mm (holotype: $5.60 \mathrm{~mm})$; width $0.80-1.30 \mathrm{~mm}(1.10 \mathrm{~mm})$.

Female (Fig. 2O)

Similar to male. Body wider than in male. Eyes somewhat smaller than in male, ratio of eye diameter to interocular space 1:5.4. Antennae distinctly shorter than in male, barely exceeding humeri, ratio of antennomere lengths: $14.5: 10: 13.5: 15: 15: 14: 14: 13: 13: 12: 15$.

Pronotum. Slightly wider than head, slightly shorter than width. Elytra conjointly about 1.4 times as wide as pronotum, about 2.8 times as long as wide. Claws simple. Abdominal ventrite VII widely emarginate on each side of terminal margin, forming subtriangular lateral lobes, median lobe moderately developed and triangularly concave in middle (Fig. 6G).

Female Genitalia (Fig. 6H). Vagina stout, abruptly extended apically as long and thick duct; diverticulum and spermathecal duct arising from apex of long duct of vagina; diverticulum moderately thin and spiral; spermathecal duct considerably shorter than diverticulum; spermatheca provided with thin spiral tube, tube shorter than diverticulum; accessory gland thin, shorter than spermatheca.

Body length 5.50-6.50 mm; width 1.20-1.50 mm.

\section{Remarks}

This species is distributed in the southern area of Taiwan at about $1000 \mathrm{~m}$ altitude according to the label data. It was observed being attracted by light at night.

Distribution (Fig. 8)

Taiwan (endemic).

Lycocerus evangelium Hsiao \& Okushima sp. nov. urn:Isid:zoobank.org:act:4AF4EFCB-BB70-44A3-BDD4-5C00B06747AE

Figs $2 \mathrm{P}-\mathrm{Q}, 5 \mathrm{~A}-\mathrm{C}, 6 \mathrm{I}-\mathrm{J}, 8$

\section{Diagnosis}

This species resembles $L$. araticollis and the nearly black form of L. nigripennis; the differential diagnosis is given in Table 3 .

\section{Etymology}

The specific epithet is derived from the Latin evangelium ("good news"), referring to fact that its discovery was good news for the team; the specific name is also in memory of the anime "Neon Genesis Evangelion", which is one of the greatest animes in Japanese history and had a strong impact on Japanese popular culture.

\section{Material examined}

\section{Holotype}

TAIWAN: $\overbrace{}^{\lambda}$, Meifeng, Nantou, 26 Apr. 2015, Y. Hsiao leg (NMNS). 
Paratypes

TAIWAN: $1 \hat{\delta}, 2$ q $q$, same data as for holotype (NMNS); $10 \hat{\jmath} \hat{\jmath}, 2$ 우, Tsuifeng, Nantou Hsien,

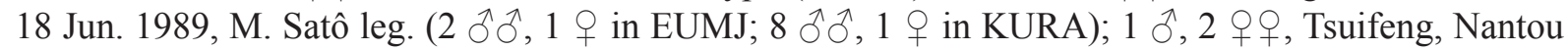
Hsien, 24 Jun. 1989, M. Satô leg. (KURA); 1 Ĵ, 3 우, Yuanfeng, Nantou Hsien, 24 Jun. 1989,

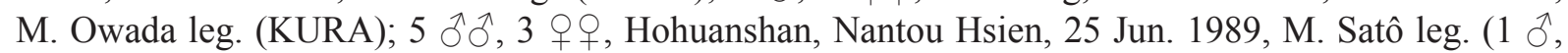

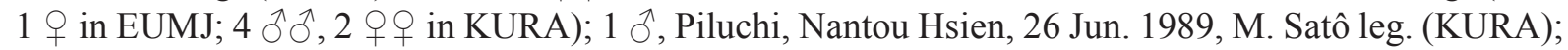

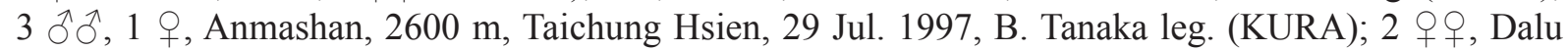
Forest Trail, Hsinchu, 21 Jun. 2008, L.-P. Hsu leg. (NMNS); 1 đ, 1 \&, Sungkang, Natou, 31 Mar. 2012, Y.-T. Wang leg. (YHC); 1 q, Liyuan, Haiduan, Taitung, 19 Apr. 2014, W.-J. Huang (NMNS); 5 우, Jianchin Historical Trail, Ilan, 1900 m, 26 Apr. 2014, Y. Hsiao leg. (3 웅 in TARI; 2 우 in YHC); 2 우으, Walami Trail, 23.344679 ${ }^{\circ} \mathrm{N}, 121.201454^{\circ} \mathrm{E}, 862 \mathrm{~m}$, Huangma, Zhuoxi County, Hualian, 28 Feb. 2015, Y.-M. Weng leg. (YHC); 2 đô, 1 q, Dabaishan, Ilan, 14 Apr. 2015, L. Huang leg. (TARI); 1 , Chiarouhu, Ilan, 25 Apr. 2015, F.-C. Hsu leg. (NMNS).

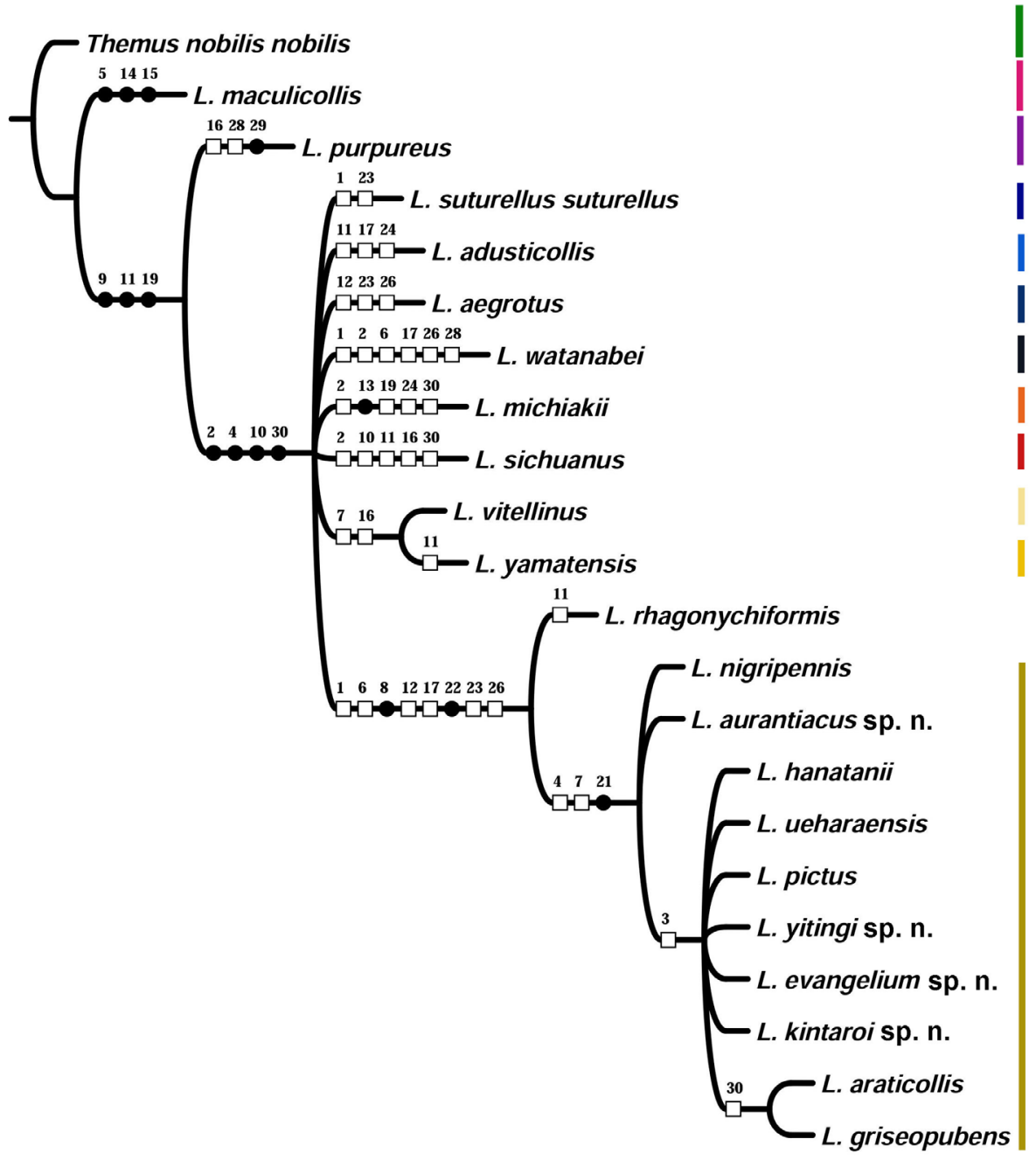

Outgroup

L. maculicollis Group

L. purpureus Group

L. suturellus Group

L. adusticollis Group

L. aegrotus Group

I L. oedemeroides Group

| L. michiakii Group

I L. hickeri Group

L. vitellinus Group

L. lineatipennis Group

\section{L. hanatanii Group}

Fig. 9. Phylogenetic reconstruction of the Lycocerus hanatanii species group. Strict consensus tree with characters mapped on branches using unambiguous character changes in WinClada. Tree length $=72$; Consistency Index $=54$; Retention Index $=72$. 


\section{Other material}

TAIWAN: 1 , Alishan, Chiayi Hsien, 17 May 1968, Y. Watanabe leg. (KURA); 2 qq, Mt. Yushan, Nantou Hsien, 20 May 1968, Y. Watanabe leg. (KURA); 1 ઈึ, 3 우으. Mt. Alishan, 27 Jul. 1970, M. Chujo leg. (1 $\delta$ in NHMB; 3 $9+$ in KURA); 1 đิ, Mt. Alishan, 28 Jul. 1970, M. Chujo leg. (NHMB); 9 §ึ, 2 우, Meifeng, Nantou Hsien, 15 Jun. 1976, T. Matsumoto leg. (KURA); 2 우, Sungkang-Meifeng, Nantou Hsien, 2 May 1977, W. Suzuki leg. (KURA); 1 đ̃, 1 क, Tsuifen, Nantou Hsien, 4 May 1979, S. Tsuyuki leg. (KURA); 1 đ̂, Nanfanshan, Kaoshun [=Kaohsiung], 28 Apr. 1981, S. Tsuyuki leg. (KURA); 1 §ิ, Lake Yenyanfu, Ilan Hsien, 29 Apr. 1982, N. Ohbayashi leg. (KURA); 1 q, Kengting Park, Pingtung Hsien, 4 May 1982, N. Ohbayashi leg. (KURA); 1 , , Shyk Shan, near Liu Kui,

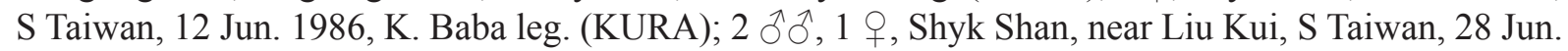
1986, K. Baba leg. (KURA); 4 q , Shi Nan Shan, near Liu Kui, S Taiwan, 23 Jul. 1986, K. Baba leg.

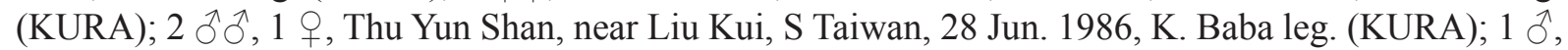
2 우, Hohuanshan, Nan Tow Hsien, M Taiwan, 6 Aug. 1986, K. Baba leg. (KURA); 1 , Twolin, Ilan Hsien, 29 Apr. 1987, N. Ohbayashi leg. (KURA); 2 đō, Meifeng, 2150 m, M Taiwan, 15 Mar. 1989, K. Baba leg. (KURA); 6 §ึ $\sigma^{2}, 2$ 우, 1 ex, Yuanfeng, Nantou Hsien, 24 Jun. 1989, M. Owada leg. (KURA); 17 đô, 2 우, 369 Cottage, Hsueshantungfeng, Taichung Hsien, 30 Jun. 1989, M. Satô leg.

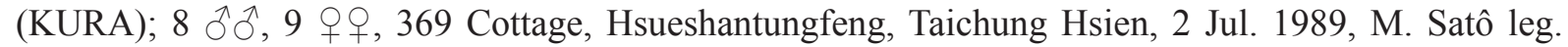

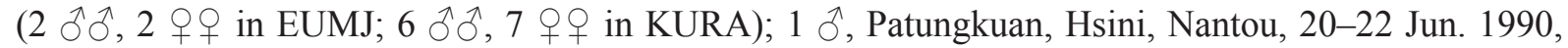
J.-T. Yang (NMNS); 1 + 230 Forest trail, Anmashan, Taichung, 3 May 1990, C.-C. Chiang (NMNS); 1 ô, Yu-shan West peak, Chiayi, 15 May 1991, C.-C. Chiang (NMNS); 1 +, Mt. Anmashan, Taichung, 2 May 1991, A. Shinohara leg. (KURA); 1 d, Chung-hsueh Shan (Erh-san-ling Lin-tao [=230 Forest trail]), 2450-2500 m, Tai-an Hsiang, Miao-li Hsien, 24 May 1991, A. Saito leg. (CBM); 1 ô, An-ma

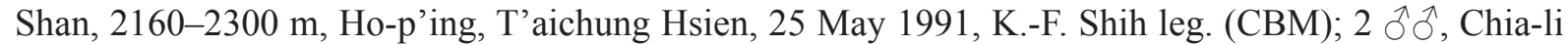
Shan, 2600-2850 m, Tai-an Hsiang, Miao-li Hsien, 27 May 1991, A. Saito leg. (CBM); 1 q, Sungkang, Nantou Hsien, 1 Jul. 1995, C. Lou leg. (KURA); 2 సิ $\widehat{~}, 1$ q, Guandoushan, Nantou Hsien, 15 Apr. 1996, C. Lou leg. (KURA); 1 đ, Tatachia, Nantou, 5 May 1998, M.-M. Yang \& S.-Y. Yang (NMNS); $1 \widehat{\partial}$, Tengchih, 1400 m, Taoyuan, Kaohsiung Hsien, 24 Mar. 2002, B. Tanaka leg. (KURA); 11 $\widehat{\partial}$, 7 q $q, 369$ Cottage, 3100 m, Hoping, Taichung, 7 Jun. 2008, W.-T. Yang leg. (NMNS); 1 o, 1 q, Yakou Country Inn, $23^{\circ} 16.063^{\prime} \mathrm{N}, 120^{\circ} 58.419^{\prime}$ E, 2582 m, Taitung County, 11 Aug. 2008, H. Mendel \& MVL Barclay leg. (BMNH).

\section{Description}

\section{Coloration}

Body and legs nearly black. Antennae dark brown to black. Mandibles yellowish brown. Body closely covered with pale pubescence; anterior margin of clypeus, antennae, elytra and legs fringed with pale bristles.

Male (Fig. 2P)

HEAD. Nearly as long as wide; vertex faintly hollowed, depressed along apical margin of clypeus and in lateral areas before eyes; surface densely and finely punctate and semilustrous; anterior margin of clypeus arcuate and faintly indented in middle; eyes not so large, globular and slightly prominent, ratio of eye diameter to interocular space 1:5.3; terminal labial palpomeres rounded ax-shaped; terminal maxillary palpomeres rounded ax-shaped; antennae filiform, extending to elytral midlength; antennomere I clavate, II short and a little expanded apicad, III to XI subcylindrical, all antennomeres without groove, ratio of antennomere lengths: $16: 10: 15.5: 20.5: 20.5: 20.5: 20.5: 20: 20: 18.5: 23$.

Pronotum. Subquadrate, about 0.90 times as wide as head, nearly as long as wide; anterior and posterior margins moderately arcuate; lateral margins feebly arcuate; anterior angles rounded; posterior angles obtuse; dorsum convex in postero-lateral and hollowed in antero-lateral areas; medio-longitudinal groove distinct in posterior half; surface smooth and semilustrous. Scutellum triangular with rounded apex. 
ELYTRA. Conjointly about 1.6 times as wide as pronotum, about 2.6 times as long as wide, sides subparallel; surface densely and finely punctate and moderately lustrous.

LEGS. Moderately slender; femora mostly straight; tibiae mostly straight, with basal part feebly arcuate; claws simple.

Aedeagus (Fig. 5A-C). Ventral process expanded and rounded apically, apex curved inwards, basal part broad and extending inwards onto ventral side; dorsal plate of each paramere as long as ventral process, broad and slightly narrowed apically, apical margin rounded, with some hairs on it, concave on inner margin. Laterophyse very short, with truncated apex, invisible in lateral view. Inner sac swollen, lengthened behind, and somewhat shorter than tegmen.

Body length 4.50-5.75 mm (holotype: $5.50 \mathrm{~mm}$ ); width 0.80-1.25 mm (1.25).

Female (Fig. 2Q)

Similar to male. Body wider than in male. Eyes smaller than in male, ratio of eye diameter to interocular space 1:6.4. Antennae distinctly shorter than in male, barely exceeding humeri, ratio of antennomere lengths: $13: 10: 14: 16: 15: 16: 14: 16: 14: 13: 16.5$.

Pronotum. About 0.95 times as wide as head, about 0.95 times as long as wide. Elytra conjointly about 1.6 times as wide as pronotum, about 2.6 times as long as wide. Claws simple. Abdominal ventrite VII widely emarginate on each side of terminal margin, forming subtriangular lateral lobes, median lobe indistinct in some specimens (Fig. 6I).

Female genitalia (Fig. 6J). Vagina stout and rounded, abruptly extended apically as long and thick duct; diverticulum and spermathecal duct arising from apex of long duct of vagina; diverticulum moderately thin and spiral, longer than spermathecal duct; spermatheca provided with thin spiral tube, tube slightly longer than diverticulum; accessory gland thin, shorter than spermatheca.

Body length 4.75-6.50 mm; width 1.50-2.25 mm.

\section{Variation}

Lateral sides of pronotum somewhat converging or diverging posteriorly; body lusterless.

\section{Remarks}

This species is widely distributed in the Central Mountain Range at mid to high altitude except one specimen collected from the Kenting Park, which is at low altitude. It appears mainly from spring to summer according to label data.

\section{Distribution (Fig. 8)}

Taiwan (endemic).

$$
\begin{aligned}
& \begin{array}{c}
\text { Lycocerus kintaroi Hsiao \& Okushima sp. nov. } \\
\text { urn:lsid:zoobank.org:act:FE9AC62A-4B2E-49A0-BD5E-58CD46500D58 }
\end{array} \\
& \text { Figs 2R, 5D-F, 8 }
\end{aligned}
$$

\section{Diagnosis}

This species can easily be distinguished from other members of this species group by the black pronotum, with yellowish fringed margins; black elytra, with very slender yellowish stripe on each humeral side; aedeagus with dorsal plate broad and subtruncated; apex of laterophyse far from apical margin of dorsal plate in lateral view. 


\section{Etymology}

The specific epithet is dedicated to its collector, the late Dr. Kintaro Baba who was one of the great Japanese entomologists.

\section{Type material}

\section{Holotype}

TAIWAN: §’, Shi Nan Shan, near Liu Kui, S Taiwan, 5 May 1986, K. Baba leg. (NMNS).

\section{Paratype}

TAIWAN: $1 \hat{\delta}$, same data as for holotype (EUMJ).

\section{Description}

\section{Coloration}

Eyes and head black. Antennae dark brown to black. Mandibles yellowish brown. Pronotum black, fringed with yellowish margins. Elytra black, with very slender yellowish stripe on each humeral side. Legs black. Pro-, meso- and metasterna, as well as abdomen blackish brown, with margins of abdominal ventrites yellowish brown. Body closely covered with pale pubescence; anterior margin of clypeus, antennae, elytra and legs fringed with pale bristles.

Male (Fig. 2R)

HEAD. Nearly as long as wide; vertex faintly hollowed, depressed along apical margin of clypeus and in lateral areas before eyes; surface densely and finely punctate and lustrous; anterior margin of clypeus arcuate and faintly indented in middle; eyes not so large, globular and slightly prominent, ratio of eye diameter to interocular space 1:5.0; terminal labial palpomeres rounded ax-shaped; terminal maxillary palpomeres rounded ax-shaped; antennae filiform, extending to elytral midlength; antennomere I clavate, II short and a little expanded apicad, III to XI subcylindrical, all antennomeres without groove, ratio of antennomere lengths: $16: 10: 13.5: 15.5: 15.5: 15: 14.5: 15: 14: 13: 14.5$.

Pronotum. Subquadrate, slightly narrower than head, about 0.95 times as long as wide; anterior and posterior margins moderately arcuate; lateral margins feebly sinuate; anterior angles rounded; posterior angles obtuse; dorsum convex in postero-lateral and hollowed in antero-lateral areas; medio-longitudinal groove distinct in posterior half; surface smooth and lustrous. Scutellum triangular, with rounded apex.

Elytra. Conjointly about 1.3 times as wide as pronotum, about 2.5 times as long as wide, sides subparallel; surface densely and finely punctate and lustrous.

Legs. Moderately slender; femora mostly straight; tibiae mostly straight, with basal part feebly arcuate; claws simple.

AEdEAGus (Fig. 5D-F). Ventral process moderately expanded and rounded apically, apex curved inwards, basal part broad and extending inwards onto ventral side; dorsal plate of each paramere as long as ventral process, broad and subtruncated, apical margin with some hairs on it, concave on inner margin. Laterophyse very short with obtuse apex, invisible in lateral view. Inner sac swollen, lengthened behind, somewhat shorter than tegmen.

Body length 5.50-6.00 mm (holotype: $5.50 \mathrm{~mm}$ ); width $1.50-1.70 \mathrm{~mm}(1.50 \mathrm{~mm})$.

\section{Female}

Unknown. 


\section{Remarks}

The right antenna of the holotype is missing.

\section{Distribution (Fig. 8)}

Taiwan (endemic).

\section{Discussion}

Members of the Lycocerus hanatanii species group have a uniform appearance, with only minor, but diagnostic differences in the structure of genitalia, which implies that these species possibly went through a relatively young history of speciation, resulting in morphological divergences that are indistinct. Due to a lack of recognized synapomorphies in the phylogenetic analysis, the relationship between other species groups and this species group as well as that among the members of L. hanatanii species group are not well-resolved. A molecular approach could solve the problem of insufficient synapomorphic characters and give higher resolution to the relationship within this species group and its phylogenetic position in Lycocerus.

In view of the greater species diversity, it seems that Taiwan is the center of origin of the L. hanatanii species group. However, in point of the origin of islands, Taiwan is a continental island, which is generally believed to have a biota related to the mainland of Eurasia (Creer et al. 2001; Jang-Liaw et

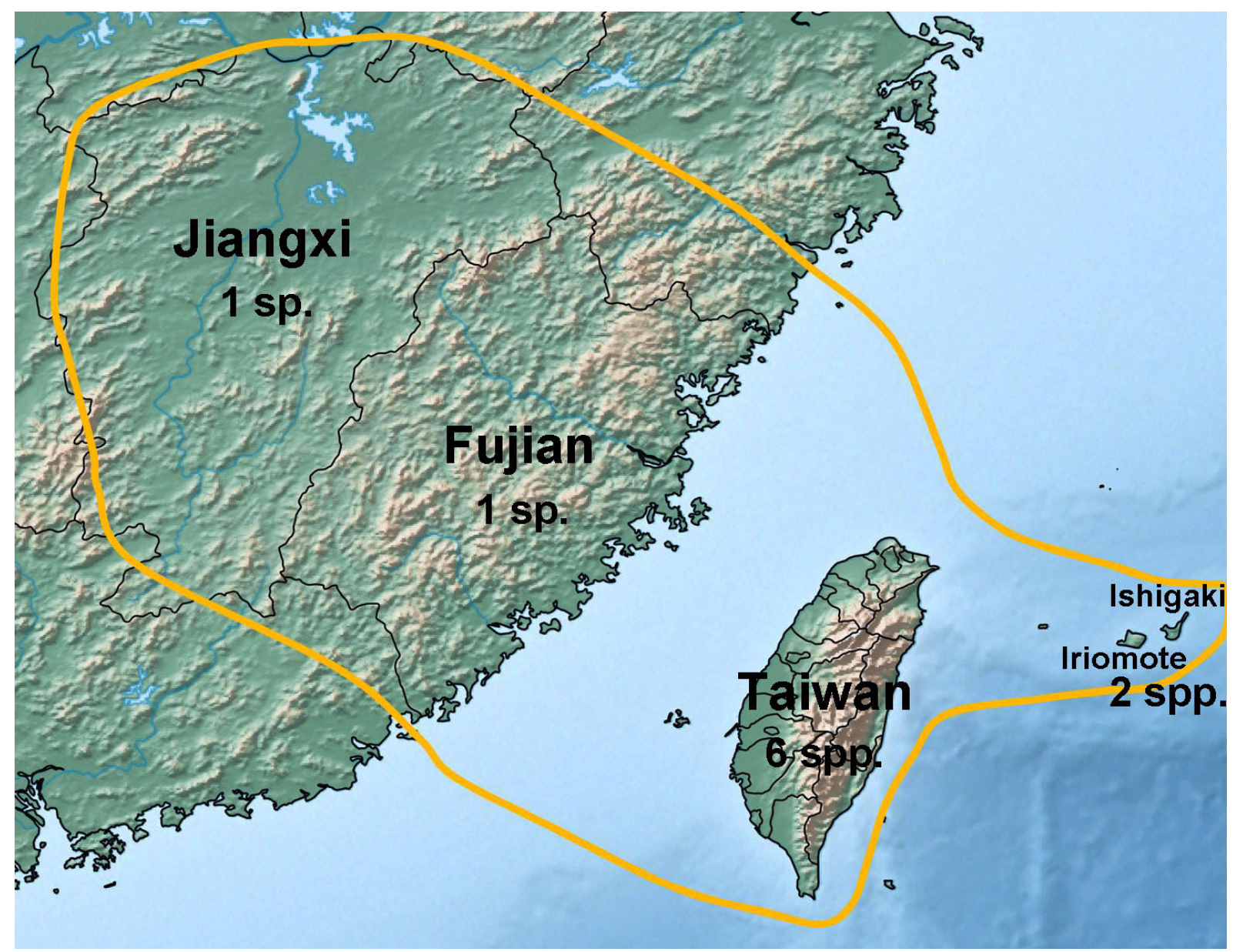

Fig. 10. Range map of the Lycocerus hanatanii species group and the number of species in each geographic region. 
al. 2008; Huang \& Lin 2011; Tsai et al. 2014). Furthermore, the taxonomy of the cantharids of China has not been studied completely yet, and it is possible that more members of this species group will be discovered and the present conjecture will be challenged or invalidated. On the other hand, according to known distribution information, this species group exhibits a China-Taiwan-Southern Ryukyus distribution pattern (Fig. 10). The speciation process of this species group, especially insular species such as L. hanatanii and L. ueharaensis, is possibly associated with the paleogeographic history of the East China Sea and the islands of eastern Asia during the Pleistocene glaciation, as in the case of the grass lizards (Lin et al. 2002). Sea level changed during this period and resulted in the appearance of a larger continental land area to provide animals the opportunity to migrate from continent to islands, then some populations were isolated when sea levels rose again, and speciation occurred. Further studies of historical biogeography are needed and will give insight into the evolutionary history of this species group.

\section{Acknowledgments}

We wish to express our hearty thanks to Dr. Darren Pollock (Eastern New Mexico University, USA) for his critical reading of the original draft of this paper and correcting our English, and to the late Dr. Masataka Satô (Nagoya, Japan), Dr. Ming-Luen Jeng (NMNS), Dr. Akiko Saito (CBM), Dr. ChiFeng Lee (TARI), Dr. Michael Geiser (BMNH), Dr. Hiroyuki Yoshitomi (Ehime University, Japan), Mr. Hiroyuki Murakami (Ehime University, Japan), Dr. Zhen-Yu Jin (Yangtze University, China), Mr. Li Huang, Mr. Yi-Ming Weng, Mr. Tien Hsieh, Mr. Ming Liu, Mr. Chi-Jung Li, Mr. Ren-Hou Liou, Mr. Wen-Chuan Liao, Mr. Yi-Ting Chung, Mr. Wen-Jean Huang, Mr. Yung-Jen Lu, Mr. Chi-Hao Wu, Mr. Chao-Pu Cheng, Mr. Shih-Hao Chang and Mr. Yu-Tang Wang for their assistance in carrying out the phylogenetic analysis or in loaning specimens or providing materials. Our thanks also go to Dr. Norm Penny (CAS), Ms. Isabelle Zürcher-Pfander (NHMB), Dr. Eckhard Groll (SDEI), Dr. Stephan Blank (SDEI) and the team of the NMNS for providing photographs, as well as to the Ministry of Science and Technology project of databasing insect type specimens collected from Taiwan that are housed abroad through grant MOST101-2631-H-178-003. Besides, we are indebted to the editor and anonymous reviewers for their suggestions in improving the manuscript.

The present study was supported financially by the Ministry of Science and Technology, Republic of China, grant MOST104-2815-C-002-057-B.

\section{References}

Creer S., Malhotra A., Thorpe R.S. \& Chou W.-H. 2001. Multiple causation of phylogeographical pattern as revealed by nested clade analysis of the bamboo viper (Trimeresurus stejnegeri) within Taiwan. Molecular Ecology 10 (8): 1967-1981. http://doi.org/10.1046/j.0962-1083.2001.01332.x

Delkeskamp K. 1977. Cantharidae. In: Wilcox J.A. (ed.) Coleopterorum Catalogus Supplementa: 1-485. W. Junk, The Hague.

Fairmaire L. 1897. Description de coléoptères nouveaux de la Malaisie, de 1'Inde et de la Chine. Notes from the Leyden Museum 19: 209-233.

Goloboff P. 1999. NONA (NO NAME), ver. 2.0. Published by the author, Tucumán, Argentina.

Hsiao Y. 2015. Description of two new species of the genus Stenothemus from Taiwan (Coleoptera: Cantharidae). Zootaxa 3937 (2): 386-392. http://dx.doi.org/10.11646/zootaxa.3937.2.9

Hsiao Y. \& Okushima Y. 2015. A new species of the genus Lycocerus (Coleoptera, Cantharidae) from Taiwan. Elytra (Tokyo), New Series 5 (1): 109-113. 
Huang J.-P. \& Lin C.-P. 2011. Lineage-specific late pleistocene expansion of an endemic subtropical gossamer-wing damselfly, Euphaea formosa, in Taiwan. BMC Evolutionary Biology 11 (1): 94. http:// dx.doi.org/10.1186/1471-2148-11-94

Jang-Liaw N.-H., Lee T.-H. \& Chou W.-H. 2008. Phylogeography of Sylvirana latouchii (Anura, Ranidae) in Taiwan. Zoological Science 25: 68-79. http://dx.doi.org/10.2108/zsj.25.68

Kasantsev S.V. 1999. Revision of Lycocerus Gorham of Indochina and adjacent regions, with the description of Walteria, a new genus (Coleoptera, Cantharidae). Entomologica Basiliensia et Collectionis Frey 21: 115-134.

Kazantsev S.V. 2007. Cantharidae. New acts and comments. In: Löbl I. \& Smetana A. (eds) Catalogue of Palaearctic Coleoptera, Vol. 4: 47-54. Apollo Books, Stenstrup, Denmark.

Kazantsev S.V. \& Brancucci M. 2007. Cantharidae. In: Löbl I. \& Smetana A. (eds) Catalogue of Palaearctic Coleoptera, Vol. 4: 234-298. Apollo Books, Stenstrup, Denmark.

Lin S., Chen C.A. \& Lue K. 2002. Molecular phylogeny and biogeography of the grass lizards genus Takydromus (Reptilia: Lacertidae) of East Asia. Molecular Phylogenetics and Evolution 22 (2): 276288. http://dx.doi.org/10.1006/mpev.2001.1059

Nixon K.C. 2002. Winclada ver. 10.00.08. Published by the author, Ithaca, NY.

Okushima Y. 1996. The genus Athemellus (Coleoptera, Cantharidae) of the Ryukyu Islands, Southwest Japan. Elytra (Tokyo) 24 (1): 113-124.

Okushima Y. 2005. A taxonomic study on the genus Lycocerus (Coleoptera, Cantharidae) from Japan, with zoogeographical considerations. Japanese Journal of Systematic Entomology (Matsuyama), Monographic Series 2: 1-383.

Okushima Y. 2007a. Three new metallic species of the genus Lycocerus (Coleoptera, Cantharidae) from Taiwan. Elytra (Tokyo) 35 (1): 129-141.

Okushima Y. 2007b. Taxonomic notes on some Lycocerus species (Coleoptera, Cantharidae) preserved in the Muséum national d'Histoire naturelle, Paris. Japanese Journal of Systematic Entomology 13 (2): $257-265$.

Okushima Y. 2008. A new species of the genus Prothemus (Coleoptera: Cantharidae) from Taiwan, with records of Taiwanese Cantharidae in the Shibata collection. Special Publication of the Japanese Coleoptera Society (Osaka) 2: 273-300.

Okushima Y. \& Brancucci M. 2008. A remarkable new species of the genus Lycocerus (Coleoptera, Cantharidae) from Indochina. Entomologica Basiliensia et Collectionis Frey 30: 41-47.

Okushima Y. \& Yang Y.-X. 2013. Two new species of the subfamily Cantharinae (Coleoptera, Cantharidae) from Taiwan. Elytra (Tokyo), New Series 3 (1): 89-96.

Pic M. 1922. Nouveautés diverses. Mélanges Exotico-Entomologiques 36: 1-32.

Pic M. 1928. Malacodermes exotiques. L'Echange, Revue Linnéenne 44: 53-56.

Pic M. 1938. Descriptions de coléoptères et notes synonymiques. Bulletin de la Société Entomologique de France 43: 121-124.

Satô M., Okushima Y., Takahashi N., Li C.-L., Yang Y.-X. \& Hsiao Y. 2015. Checklist of the Cantharidae of Taiwan (Coleoptera: Elateroidea). Collection and Research 27: 43-69.

Shorthouse D.P. 2010. SimpleMappr, an Online Tool to Produce Publication-Quality Point Maps. Available from http://www.simplemappr.net [accessed 23 Aug. 2015]

Takahashi K. 1998. Check-list of Cantharidae of Japan. Kanagawa-Chûhô (Odawara) 122: 29-48. 
HSIAO Y. et al., Revision of the Lycocerus hanatanii species group

Tsai C.-L., Wan X. \& Yeh W.-B. 2014. Differentiation in stag beetles, Neolucanus swinhoei complex (Coleoptera: Lucanidae): Four major lineages caused by periodical Pleistocene glaciations and separation by a mountain range. Molecular Phylogenetics and Evolution 78: 245-259. http://doi.org/10.1016/j. ympev.2014.05.004

Wittmer W. 1954. Zur Kenntnis der Cantharidae der Insel Formosa (19. Beitrag zur Kenntnis der palaearktischen Malacodermata, Col.). Revue Suisse de Zoologie 61: 271-282. Available from http:// biodiversitylibrary.org/page/40777837 [accessed 11 Dec. 2015]

Wittmer W. 1972. 55. Beitrag zur Kenntnis der palaearktischen Cantharidae und Malachiidae (Col.). Entomologischen Arbeiten aus dem Museum G. Frey 23: 122-141.

Wittmer W. 1983. Die Familie Cantharidae (Col.) auf Taiwan (2. Teil). Entomological Review of Japan (Osaka) 38: 147-172.

Yang Y.-X. \& Yang X.-K. 2011. Lycocerus strictipennis sp. nov. from Yunnan, China, the second species in the michiakii species-group of Lycocerus Gorham (Coleoptera: Cantharidae). Annales Zoologici 61 (4): 637-640. http://dx.doi.org/10.3161/000345411X622480

Yang Y.-X., Su J.-Y. \& Yang X.-K. 2014. Description of six new species of Lycocerus Gorham (Coleoptera, Cantharidae), with taxonomic note and new distribution data of some other species. ZooKeys 456: 85107. http://dx.doi.org/10.3897/zookeys.456.8465

Manuscript received: 6 September 2015

Manuscript accepted: 3 November 2015

Published on: 5 January 2016

Topic editor: Koen Martens

Desk editor: Danny Eibye-Jacobsen

Printed versions of all papers are also deposited in the libraries of the institutes that are members of the EJT consortium: Muséum National d'Histoire Naturelle, Paris, France; Botanic Garden Meise, Belgium; Royal Museum for Central Africa, Tervuren, Belgium; Natural History Museum, London, United Kingdom; Royal Belgian Institute of Natural Sciences, Brussels, Belgium; Natural History Museum of Denmark, Copenhagen, Denmark. 